NBER WORKING PAPER SERIES

\title{
ECONOMIC CRISES AND MENTAL HEALTH: EFFECTS OF THE GREAT RECESSION ON OLDER AMERICANS
}

\author{
David M. Cutler \\ Noémie Sportiche \\ Working Paper 29817 \\ http://www.nber.org/papers/w29817 \\ NATIONAL BUREAU OF ECONOMIC RESEARCH \\ 1050 Massachusetts Avenue \\ Cambridge, MA 02138 \\ March 2022, Revised June 2022
}

This research was supported by the U.S. Social Security Administration through grant \# DRC12000002-04 to the National Bureau of Economic Research as part of the SSA Disability Research Consortium and the National Institute of Mental Health of the National Institutes of Health under Award Number T32MH019733. We are grateful to Susan Stewart for advice and comments. The findings and conclusions expressed are solely those of the authors and do not represent the views of SSA, any agency of the Federal Government, or the National Bureau of Economic Research (NBER).

NBER working papers are circulated for discussion and comment purposes. They have not been peer-reviewed or been subject to the review by the NBER Board of Directors that accompanies official NBER publications.

(C) 2022 by David M. Cutler and Noémie Sportiche. All rights reserved. Short sections of text, not to exceed two paragraphs, may be quoted without explicit permission provided that full credit, including $\odot$ notice, is given to the source. 
Economic Crises and Mental Health: Effects of the Great Recession on Older Americans

David M. Cutler and Noémie Sportiche

NBER Working Paper No. 29817

March 2022, Revised June 2022

JEL No. I1

\begin{abstract}
$\underline{\text { ABSTRACT }}$
We examine the effect of the Great Recession of 2007-2009 on the mental health of older adults, using longitudinal Health and Retirement Study data linked to area-level data on house prices. We use a variety of measures to capture mental health and rely on the very large cross-sectional variation in falling house prices to identify the impact of the Great Recession on those outcomes. We also account for people who moved in response to falling prices by fixing each person's location immediately prior to the house price collapse. Our central finding is that the Great Recession had heterogeneous effects on health. While mental health was not affected for the average older adult, mental health declined among homeowners with few financial assets, who were therefore more vulnerable to falling house prices. Importantly, health impacts in this group differed by race and ethnicity: depression and functional limitations worsened among Black and other non-white homeowners and medication use increased among white homeowners. There were no measurable impacts for Hispanic homeowners. These results highlight the importance of examining heterogeneity across multiple dimensions when examining the health impacts of economic conditions.
\end{abstract}

David M. Cutler

Department of Economics

Harvard University

1875 Cambridge Street

Cambridge, MA 02138

and NBER

dcutler@harvard.edu

Noémie Sportiche

Harvard University

njs148@g.harvard.edu 
The Great Recession of 2007 to 2009 was the largest economic downturn in the United States since the Great Depression. During the recession, house prices fell by over a third of GDP (Mian and Sufi, 2015), unemployment rose by five percentage points (Bureau of Labor Statistics, 2012), the poverty rates rose two percentage points (Danziger et al., 2018), and four million people had their homes foreclosed upon (Mian and Sufi, 2015). The economic downturn persisted well beyond the recession's official end. For example, house prices continued to decline for several more years such that nearly one in four homeowners with a mortgage was "underwater" by 2011 (Ellen and Dastrup, 2012; Mian and Sufi, 2015).

How did this massive economic downturn affect people's health? Most of the literature on economic conditions and health focuses on mortality as the measure of health. This literature suggests an inverse relationship between economic productivity and health, where mortality declines during times of economic hardship and rises during expansion years (Tapia Granados, 2005; Tapia Granados and Roux, 2009; Tapia Granados and Ionides, 2017; Ruhm, 2000, 2003, 2005; Neumayer, 2004), though recent evidence shows that mortality did not fall during the Great Recession (McInerney and Mellor, 2012; Ruhm, 2015).

However, these overall trends in mortality mask considerable heterogeneity in the effects of economic conditions on specific causes of death. Mortality fell during previous recessions because of declines in industrial accidents, automobile accidents, pollution-related deaths, and nursing home deaths (Heutel and Ruhm, 2016; Miller et al., 2009; Ruhm, 2003; Stevens et al., 2015). Other causes of death rise. For example, suicides increase during recessions (Barr et al., 2012; Nandi et al., 2012; Tapia Granados and Roux, 2009) and job losers are specifically at higher risk of death (Tapia Granados et al., 2014). One potential explanation for this rise in suicides is that mental health declines (Christian et al., 2019; Kuhn et al., 2009).

In this paper, we examine the impact of the Great Recession on three sets of health outcomes, all related to mental health: symptoms of depression; chronic pain severity and functional limitations; and the use of medications to treat sleep, depression, and/or anxiety. 
We emphasize these outcomes as mental health likely responds differently to changing economic conditions than physical health (Frasquilho et al., 2016; Stuckler et al., 2009; Ruhm, 2015) and poor mental health may be particularly disruptive to a person's life (Millan et al., 2012; Ridley et al., 2020). Furthermore, the long-run impacts of recessions may be driven by changes to morbidity rather than mortality, including earnings reductions due to poor mental health (Frank and Glied, 2018; Luciano et al., 2014; Millan et al., 2012) and impacts of sustained exposure to prescription opioids (Case and Deaton, 2015).

Our analysis focuses on pre-retirement adults - a population that may be particularly vulnerable to the Great Recession's impacts - using data from the Health and Retirement Study (HRS), a nationally representative panel survey of adults over the age of 51. To identify the effects of the Great Recession on health, we take advantage of the enormous cross-sectional variation in the extent of house price decline (Mian and Sufi, 2015). For example, while house prices in Phoenix and Las Vegas fell by 46 and 60 percent between 2006 and 2012 respectively, house prices in Pittsburgh and Buffalo increased by five and six percent. ${ }^{1}$ We test whether areas with greater reductions in house prices had worse health outcomes. Then, we examine the distribution of health effects across groups with different levels of baseline economic vulnerability. We use data from 2000 to 2016, a range that includes the years of the largest house price declines (late 2006 to 2012) along with several pre-and post- collapse years.

To assess the impact of house price changes on mental health, we estimate fixed effects models for individual outcomes as a function of house price changes in the area they lived in immediately prior to the Great Recession. Using individuals' pre-recession location controls for the fact that people may relocate in response to the Great Recession. We examine the population overall and focus on outcomes for groups where one might expect effects of house price changes to be greatest: Black, other non-white, and Hispanic households; households

\footnotetext{
${ }^{1}$ Calculated based on FHFA house price index data prepared by (Bogin et al., 2019).
} 
with less education; and those with few assets outside of the housing market (Hoynes et al., 2012; McKernan et al., 2014; Mian and Sufi, 2015; Pfeffer et al., 2013; Rugh and Massey, $2010) .^{2}$

Our central finding is that the Great Recession had a heterogeneous effect on mental health. While there was no discernible effect of the Great Recession on mental health overall, the collapse worsened mental health for those with fewer financial assets, who were therefore more economically vulnerable to the housing market's effects. Further, health impacts in this group differed by race and ethnicity: depression and functional limitations worsened among Black and other non-white homeowners, medication use increased among white homeowners, and Hispanic homeowners appear to have been unaffected. Moreover, Black and other non-white homeowners were affected at nearly all levels of financial assets, while white homeowners were affected only at lower levels of wealth, especially in households with lower levels of education. Because affected homeowners were already in worse health at baseline, our findings imply that the Great Recession widened health disparities among older adults. We examine several possible explanations for these findings. None of the mechanisms we tested, including foreclosure, individual loss of housing wealth, social isolation, family network instability, or perceived neighborhood conditions fully explains the house-price-to-health relationship. This implies that house prices matter for some other reason. Further, we find no evidence that health effects scale with income or wealth losses; only vulnerability to housing market fluctuations seemed to matter for the Great Recession's impact on mental health.

Our study makes several contributions to the literature. First, it expands the range of health outcomes that are associated with economic fluctuations, moving beyond the longstanding focus on mortality. There is a small literature which finds that mental health

2 For example, while the net worth of wealthy households was barely affected between 2007 and 2010, the net worth of poor households was almost completely wiped out (Mian and Sufi, 2015). 
declines during recessions (Charles and DeCicca, 2008; Frasquilho et al., 2016; Ruhm, 2003; Stuckler et al., 2009), but it is mostly focused on suicides and overall average effects rather than morbidity or differences across subgroups. Second, our examination of heterogeneity across racial and economic groups provides insight into who suffers the most as a result of downturns. Despite evidence that the effects of the recession are disproportionately concentrated on disadvantaged households (Hoynes et al., 2012; McKernan et al., 2014; Mian and Sufi, 2015), ours is among the few papers to examine differential effects on health (Currie et al., 2015). Third, because we use house prices rather than unemployment as our key exposure variable, we contribute new insight into the overall impact of the Great Recession on health mediated through housing markets. For the Great Recession in particular, where many people moved out of the labor force, we expect the health impact of foreclosures (Currie and Tekin, 2015; Downing, 2016) and lost housing wealth (Swope and Hernández, 2019; Yilmazer et al., 2015) to be better captured by area house prices than by unemployment. Finally, our results also contribute to a growing literature on the relationship between health and housing (Downing, 2016; Krieger and Higgins, 2002; Swope and Hernández, 2019) which mostly examines the impact of individual-level exposures (e.g., foreclosure, housing wealth, lead paint) on health, rather than that of exposures at the scale of an entire housing market.

The remainder of this paper is organized as follows. Section I describes our data, empirical strategy, and key measures of health and the Great Recession. Section II presents our results and section III examines the robustness of those findings. Section IV then explores potential mechanisms for the change in mental health. We conclude by discussing the implications of these findings.

\section{Data and Empirical Strategy}

We use data from the Health and Retirement Study (HRS) — an ongoing nationally representative panel survey of more than 22,000 adults aged 51 and over. The HRS interviews respondents every even-numbered year on a wide range of subjects relevant to aging pop- 
ulations, including health, housing, assets, relationships, and employment. To capture the period before and after the Great Recession, we use data from 2000 to 2016.

Our target population is people who were 51 to 61 ("pre-retirement" adults) between 2000 and 2016. Respondents aged 62 to 64 are omitted to leave out early retirees and anticipatory effects related to retirement at age 65 . Because they tend to be sicker, we also exclude those who receive disability insurance (SSDI) starting from the first year they are on SSDI. Our analysis sample has 9,425 people (27,887 observations) who were between 51 and 61 at some point between 2000 and $2016 .{ }^{3}$ Sample demographics are shown in the first column of Appendix Table A.1. Prior to the decline in house prices, the median pre-retirement adult had about $\$ 125,000$ of accumulated housing wealth, $\$ 70,000$ in financial assets, and on average reported being in mostly decent health or slightly better than "good" overall health $($ score $=3.5)$, few depressive symptoms (CES-D of 1.34) or functional limitations (1.3 on average), little to no pain (score $=0.50)$, and little sleep medication use $(12 \%)$. However, medication use for anxiety and/or depression was common (55\%).

When broken out by magnitude of house price decline, pre-retirement adults in high price decline areas (column 2) are somewhat more racially and ethnically diverse, educated, wealthier, and healthier when compared to the composition of pre-retirement adults in low price collapse areas (column 3).

Using restricted-access geocoded information, we match people to the core-based statistical area (CBSA) they live in. When HRS respondents live in a rural area outside of a designated CBSA, we match HPI data to respondents by state. ${ }^{4}$ As noted below, we match

${ }^{3}$ We begin with a sample of 42,053 people. Of these, we drop 14,361 people because they are missing survey responses between 2000 and 2004 when we assign geographic locations (see empirical methodology section), 3,297 people for having no observations within our study period, 14,078 people for being outside the ages of 51 and 61,795 people for receiving disability insurance (SSDI), and 97 people because they either had a single observation or were missing on key variables (e.g., HPI). This leaves us with a final sample of 9,425 people and 27,887 observations.

4 We use a five-digit zip code to state crosswalk to accomplish this match. Zip codes can occasionally cross state boundaries, but this is a very small share of the sample. 
people to their housing location prior to $2006^{5}$, even if a person moved after that time.

We obtain area house prices from the Federal Housing Finance Agency's yearly House Price Index (denoted HPI). The FHFA's HPI is a weighted repeat-sales index of single-family house prices whose mortgages have been purchased or securitized by Fannie Mae or Freddie Mac (Bogin et al., 2019).

House prices are normalized to 100 in all areas in 2000. Normalized house prices reached a high of 154 in 2006 and fell to a local minimum of 122 in 2012. For graphical purposes, our "treatment" period is 2006 to 2012 (Ellen and Dastrup, 2012; Gyourko and Molloy, 2015). To establish a pre- and post-time period, we use data from the 2000 to 2004 and 2014 to 2016 waves of the HRS. ${ }^{6}$

\section{Dependent Variables: Mental Health and Medication Use}

We use three sets of measures to capture mental health changes, including: symptoms of depression; chronic pain severity and functional limitations; and the use of medications to treat sleep, and separately, depression, and/or anxiety. These outcomes are central to the health of an aging population (Chatterji et al., 2015).

Symptoms of depression are measured using the Center for Epidemiology and Depression (CES-D) 8 (Kohout et al., 1993; Radloff, 1977; Vilagut et al., 2016). The CES-D is scaled from 0 (no signs of depression) to 8 (all measured signs of depression are present) based on six indicators of negative affect or somaticism and two indicators of diminished positive affect. Appendix Table A.2 shows the exact questions used in all our health measures, including the CES-D 8.

Chronic pain and functional limitations can also be manifestations of depression, which often present primarily as physical symptoms, such as chronic joint, limb, or back pain; sleep

\footnotetext{
${ }^{5}$ We fix geographic location to the most recent observation prior to 2006.

6 Survey sampling typically takes place starting around March of the survey year and continues for about one year. Thus, each survey actually captures reports from a broader time period that overlaps with the subsequent year.
} 
disturbances; and psychomotor changes (Trivedi, 2004). ${ }^{7}$ We measure chronic pain based on two questions from the HRS which capture frequency and severity of pain experienced by respondents, while functional limitations is the sum of seven indicators of difficulty with everyday activities related to mobility (see Appendix Table A.2 for specific questions). Chronic pain scores range from 0 (no pain) to 3 (severe pain) and functional limitation scores range from 0 (no limitations) to 7 (all limitations).

Finally, we include two measures of medication use related to mental health. Medication use for anxiety and/or depression (a.k.a select mood disorders) is a binary indicator where one indicates current use of "tranquilizers, antidepressants, or pills for nerves." Sleep medication use is also a binary indicator and captures the regular use of prescription medications to sleep. Both indicators are only available for part of the study period. The indicator for anxiety and/or depression is available from 2000 to 2012, and the indicator for sleep medication use is only asked of a subsample of HRS participants between 2006 to $2016 .^{8}$

\section{Empirical Methodology}

We use geographic variability in the extent of house price changes during the Great Recession to identify the impact on mental health. The severity of the Great Recession varied widely across areas. The unemployment rate rose on average by five percentage points between 2006 and 2010, but the standard deviation of this change across CBSAs was two percentage points.

In addition to high unemployment, the Great Recession also involved significant house price changes. Between 2006 and 2012, house prices fell 34 percent on average (see Appendix

7 A large proportion of patients only report somatic symptoms when seeking care for depression and relying only on direct reports of mental symptoms may miss a large fraction of cases (Simon et al., 1999).

8 Sleep medication use is asked as part of the Leave Behind Questionnaire (LBQ), a module that was piloted in 2004 before beginning in 2006. Each wave, half of HRS respondents are randomly selected to be surveyed in person and half are surveyed via phone. The LBQ is left behind at the end of the in-person interviews. 
B.1 for a breakdown of house price changes by CBSA). The correlation between the increase in the unemployment rate and the decline in house prices at the area level is high: 0.76.

In our analysis, we proxy for the impact of the Great Recession with area-specific house price changes. We use house price changes instead of unemployment for three reasons: the large drop in house prices preceded the rise in unemployment (Mian and Sufi, 2015) and precipitated a very large decrease in construction employment (Hadi, 2011); the unemployment rate omits people who leave the labor force; and changes to wealth or general housing circumstances may affect health even for people who remain employed.

A potential issue in using area-specific house price changes to measure the impact of the recession is that people may relocate in response to changing prices. Though this does not occur frequently in our sample of 51-61-year-olds - only four percent of people changed CBSAs between 2006 and 2012 - we nevertheless control for these moves by fixing each person's place of residence throughout the study period to the most recent location we observe prior to the 2006 survey (i.e., in 2004, 2002, or 2000). The equation we estimate is of the form ${ }^{9}$ :

$$
\mathrm{MH}_{i, c, t}=\alpha+\beta \mathrm{HPI}_{c(p r e-2006), t}+\delta X_{i, c, t}+\gamma_{t}+\lambda_{i}+\epsilon_{i, c, t}
$$

In equation (1), i denotes individuals, c the CBSA, and t the year. Mental health outcome MH is assumed to depend on area-level house prices indexed to the location of residence prior to 2006 (HPI), individual and year fixed effects $\left(\lambda_{i}\right.$ and $\gamma_{t}$, respectively), and a vector $X$ of individual demographic, economic, and health characteristics, which may vary over time. Time-varying characteristics specified in $X$ (in year t) include demographics (five-year age groups interacted with gender, marital status); economic variables (quantiles of non-housing financial assets, labor force status, housing tenure, tenure interacted with education); and health characteristics (indicators of diagnosis with heart disease, stroke, high blood pressure,

9 This is the reduced form version of an IV model instrumenting for current house prices with house prices as of the pre-Great Recession year. 
diabetes cancer, arthritis, lung disease). The presence of individual fixed effects excludes the need for time independent variables like race and education. We also include an indicator for whether the respondent is in their first wave of the HRS as participants tend to be healthier the first time they appear in the survey (Hurd et al., 2014). Finally, we interact tenure with education based on previous research showing that rates of homeownership and depression differ by educational attainment (Gyourko and Linneman, 1997).

Equation (1) specifies house prices as the index, rather than the log of the index. Given that the index is normalized to 100 in 2000, the difference between the two specifications is not material, and none of our results change if we use the logarithm of the house price index.

Standard errors are clustered at the CBSA-level to adjust for correlated health outcomes within areas and regressions are weighted to approximate the population of pre-retirement adults and seniors in the US.

\section{Mental Health Effects of the House Price Collapse}

We begin illustrating our results with Figure 1, which compares mental health trends in areas where house prices fell more than average between 2006 and 2012 to those areas where prices fell less than average over the same time period. As noted above, each individual's location is fixed according to where they lived immediately prior to the recession's onset in 2006. In all cases, higher numbers indicate worse mental health.

If the house price collapse affected mental health, we would expect to see greater change in mental health indicators during the recession for people living in areas with greater declines in house prices than for people living in areas with lesser declines in house prices. The fact that we observe no such difference in trends implies that the magnitude of the house price collapse had no effect on average mental health in the overall population.

Figure 1 also provides no evidence of a population-wide decline in mental health during the study period. For example, the maximum increase in depression across both groups is 
about two percentage points, which, as we describe below, translates to about one fifth of the magnitude of the increase associated with losing a spouse.

Table 1, which presents the estimates from equation (1), formally demonstrates these results. ${ }^{10}$ Each column in Table 1 corresponds to one of the five dependent variables while each set of rows corresponds to a different sample of pre-retirement adults. The first set of rows correspond to Figure 1. Because our measure of the house price index is an annual average, results should be interpreted as the effect of year-to-year changes in the house price index on mental health.

As the estimates in the first set of rows show, none of the coefficients on the house price index (HPI) term are statistically significant, and the magnitude of the estimated coefficients is relatively small. For example, the coefficient of -0.067 in column 1 implies that an average decline in house prices of 35 points between 2006 and 2012 predicts a 0.3 percentage point increase in depressive symptoms.

Comparing this 0.3 percentage point change to the magnitude of coefficients for other major life events known to affect depression shows that this effect is substantively small. For example, moving out of the labor force (column 1 row two) is associated with a threepercentage point increase in depressive symptoms, while losing a spouse (column 1 row three) predicts a 10 percentage point increase. These estimates are ten to thirty times greater than the predicted impact of the house price decline during the Great Recession.

To explore these results further, we subset our sample into non-homeowners, those who owned a home before 2006, and, of those homeowners, those who owned no more than one home. This allows us to separate renters and other non-owners from homeowners, who may be differentially affected by the house price collapse. The economic shock that affects homeowners may affect renters as well, though the mechanisms are likely to be different (e.g., lower income neighborhoods with more renters may deteriorate more than other areas

\footnotetext{
10 See Appendix Table A.3 for the full model results.
} 
as house prices decline). For this reason, we do not use renters as a 'control' group in a difference-in-differences setting.

The estimates for these three subsamples are shown in the second, third, and fourth sets of rows in Table 1. These results align with the results from the first set. Even among homeowners with only one home, there is no evidence that house price changes affected the average older adult's mental health.

\section{Heterogeneous Effects of Economic Conditions on Mental Health}

Even if the house price collapse did not affect mental health on average, economic downturns may have greater effects on some subpopulations. Our next analyses focus on groups who are identified in previous work as having borne the brunt of the crisis and who also had some degree of accumulated economic disadvantage prior to its onset. This includes people who identify as Hispanic, Black, or another non-white race; those with lower levels of educational attainment; and homeowners with fewer financial assets (Hall et al., 2015; Hoynes et al., 2012; McKernan et al., 2014; Mian and Sufi, 2015; Pfeffer et al., 2013; Rothstein, 2017; Rugh and Massey, 2010). We also include recent homeowners in this group, as people who acquired a home shortly before the collapse will have a relatively higher debt ratio than longer-term homeowners and may therefore be more affected by the dramatic decline in housing values when compared to longer-term homeowners. ${ }^{11}$

11 We define recent homeowners as those who bought a home within two years prior to the collapse (i.e., in 2004) unless they were missing survey data in 2004. For those missing 2004 data, we define recent homeownership based on whether they bought a home in 2002. By this definition, about 1.2 percent of our final sample are recent homeowners. Ninety nine percent of those homeowners had data from the 2004 wave of the HRS. To draw a comparison across tenure groups, we also subset our sample into longer-term homeowners, non-homeowners, and recent sellers. We categorize participants as longer-term owners or non-homeowners if they had constant tenure for the two most recent consecutive waves prior to 2006 (e.g., owned in 2002 and 2004). We define recent sellers as those who went from being homeowners to no longer owning in the two most recent waves prior to 2006. Ninety seven percent of longer-term homeowners were owners in 2002 and 2004. The remaining percent of cases consist of participants who were homeowners in 2000 and 2004 but were missing in the 2002 year. Ninety five percent of non-homeowners reported not owning a home in 2002 and 2004 and 92 percent of sellers in our sample changed 
Because effects may also have been larger for people that fall into more than one of these subpopulations (e.g., a person who is both Hispanic and has less education), we also consider heterogeneous health impacts for people belonging to multiple groups.

Appendix Table A.4 shows that nearly 90 percent of the pre-retirement adults in our sample fall into at least one of these subpopulations. As expected, each of these groups reports worse overall health, more depressive symptoms, and more functional limitations than the overall sample. The only exception is medication use, which is lower for people identifying as Black, another non-white race, or Hispanic than it is for the overall sample. Of those for whom we know longer-term housing status, 84 percent are longer-term homeowners, 10 percent are non-homeowners, and three percent each are recent buyers or sellers. Nonhomeowners and recent buyers or sellers are all more economically vulnerable than longerterm owners: they have lower levels of education, fewer financial assets, less housing wealth, and tend to be in worse health overall.

Tables 2 and 3 show the results of our subanalyses. Table 2 shows the differential responses across subgroups. Rows show the interaction of the house price index in equation (1) with indicators for each of the populations outlined above. Table 3 then shows racial and ethnic variability within several groups: fewer financial assets $\left(<\$ 75,000^{12}\right.$; panel 1$)$, lower educational attainment ( $<$ College Degree; panel 2), and both categories at once (panel 3). ${ }^{13}$ In both tables, rows show the additional effect of the house price index for a subgroup (Table 2) or the main effect of the house price index for the group in that row and panel (Table 3). Columns correspond to mental health outcomes.

tenure status in 2004 .

$12 \$ 75,000$ corresponds roughly to the population-weighted median quantity of financial assets across all years.

13 We do not examine variability within tenure due to small sample sizes and only focus on homeowners to simplify the interpretation of our results. We also pool race and ethnicity to account for small sample sizes (e.g., white homeowners include both white homeowners who identify as Hispanic and those who do not). Appendix Tables A.5 and A.6 show that decomposing analyses by race and ethnicity does not affect the interpretation of our results. 
Table 2 shows few consistent statistical differences between subgroups. Though the magnitude and direction of coefficients differ across subgroups, almost none are statistically significant.

However, Table 3 demonstrates that this masks some heterogeneity in health effects for members of multiple groups. For example, columns 1 and 3 of panel 1 show that as the house price index falls, depression and functional limitations increase among Black and other nonwhite homeowners but not among Hispanic or white homeowners. In contrast, columns 4 and 5 suggest that medication use rises by a similar amount across all groups as the house price index falls, but this effect is only statistically significant among older white adults.

To build intuition for these results, Figures 2 and 3 depict the mental health trends for the populations shown in panel 1 of Table 3. Figure 2 shows mental health outcomes and Figure 3 shows medication use. Like Figure 1, these plots compare mean age-adjusted mental health trends in high price decline areas to those in low price decline areas. As with Table 3, rows correspond to subgroups and columns to outcomes: depressive symptoms, chronic pain, and functional limitations (Figure 2), and taking medications for anxiety and sleep (Figure 3).

The first rows of both figures show that homeowners with above-median financial assets saw no changes in mental health, either overall or in areas with particularly large house price declines. Trends among homeowners with fewer assets diverge when decomposed by race and ethnicity (rows 3 to 5 ). Figure 2 shows that among Black and other non-white homeowners (row 3), rates of depression, functional limitations, and-to a lesser extent medication use - diverged for those with large and small house price changes, but chronic pain did not. While depression and functional limitations rose over time in areas where house prices fell more than average, they steadily declined in areas where house prices fell less than average. Patterns differed for white homeowners (row 4) and Hispanic homeowners (row 5). Among white homeowners, trends in depression and functional limitations remained constant but trends in medication use (Figure 3) diverged in high-vs.-low price decline areas. 
No clear trends emerge among Hispanic homeowners (row 5). ${ }^{14}$ Chronic pain followed similar trends across all groups.

The first panel of Table 3 shows that the magnitude of estimated coefficients among Black and other non-white homeowners are substantively large. For example, among Black and other non-white homeowners living in an area where house prices fell by the average of 35 points, our model predicts a three-percentage point increase in depressive symptoms (column 1 of panel 1). This effect is roughly equivalent to the increase in depression associated with moving out of the labor force predicted by our models. Similarly, our model estimates a three-percentage point increase in functional limitations per 35-point drop in the house price index for functional limitations, a value which is three times larger than the effect of aging five years for this same group.

Panel 1 also shows that estimated coefficients are large among white homeowners with fewer financial assets. In this group, the chance a person reports using anxiety/depression medication or sleep medication increased by six percentage points and four percentage points, respectively, when house prices fell by the average value of 35 points.

Panels 2 and 3 of Table 3 show similar results. Though the magnitude of the coefficients for the house price index decrease in panel 2 and increase in panel 3, they remain similar to the coefficients in panel 1 both in magnitude and direction.

These results suggest larger mental health effects of house price declines among the population with fewer assets than among the population with more assets. To examine trends in the house-price-to-health relationship, we vary the threshold for financial assets and/or education and examine the consequences for the coefficient for the house price index. We demonstrate these results in Figure 4, which shows the results from panel 1 of Table 3. The results from panels 2 and 3 of Table 3 can be found in Appendix Figures B.2 and B.3.

\footnotetext{
14 Figure 2 suggests that anxiety and depression medication use followed different trajectories among Hispanic homeowners (see column 5), but these are not corroborated by the results of our regressions (presented in Table 3).
} 
In all three figures, rows correspond to subgroups, and columns correspond to mental health outcomes. In Figure 4 and Appendix Figure B.3, we vary the financial assets threshold in 10 percentile increments, from roughly the 30 th to the 80 th percentiles of financial assets. In Appendix Figure B.2, we vary the education threshold between four levels of educational attainment: less than a high school degree, a high school degree, some college, and a college degree or more.

The estimates in these figures show that the coefficients remain statistically significant across a range of specifications, confirming our earlier results. In Figure 4, the magnitude of estimated coefficients on depression also increases as we subset to increasingly asset-poor households (e.g., the magnitude of the coefficient on the house price index for depression increases by about 75 percent when lowering the asset threshold from $\$ 150,000$ to $\$ 25,000$ among Black and other non-white households). We do not observe this pattern with functional limitations, though they are only marginally not significant. We also confirm no clear patterns among Hispanic households.

Notably, mental health effects for Black and other non-white homeowners persist at higher levels of wealth than for white homeowners. Mental health effects for white homeowners emerge below roughly $\$ 75,000$ in financial assets and only follow a clear trend if we also subset to groups with less education. Among Black and other non-white homeowners, effects on depression persist for all but those with the very highest levels of financial assets.

\section{Tests of Robustness}

Because the Great Recession affected everyone, there is no perfect control group for our analyses. We therefore test our results not with a formal difference-in-differences design but rather by looking at a population that should be less affected by the house price collapse: 
a national representative population of seniors aged 65 to $74 .^{15}$ Though seniors might still be affected by the house price collapse for a variety of reasons, ${ }^{16}$ they are likely to be less affected by the labor market implications of house price decline, including the loss of health insurance. $^{17}$

Appendix Tables C.1 to C.3 show results for this age group, analogous to Tables 1 to 3 above. The data show that seniors were not affected by the house price collapse to the same extent or in the same way as pre-retirement adults. Across all three tables, coefficients on the house price index tend to be both small and statistically insignificant, despite much larger sample sizes. Appendix Table B.3 suggests that there is some heterogeneity in chronic pain severity, wherein Hispanic seniors may be negatively affected by declining house prices, but we observe no statistical differences across groups for other health outcomes.

We also run a series of tests among seniors summarized in Appendix Tables C.4 to C.6-again equivalent to Tables 1 to 3 -which substitute the unemployment rate for the house price index as the key exposure variable. This substitution reveals that changes in the unemployment rate do not predict changes in health as precisely as house prices do. While the direction of estimated coefficients is largely consistent with models fit using the house price index, large standard errors show substantial uncertainty around these estimates. This is consistent with the idea that capturing the effects of the Great Recession are better proxied by changes to house price than by changes to unemployment.

\footnotetext{
15 We exclude seniors 75 and over as they generally tend to be sicker and more detached from the housing market (e.g., living with family or in nursing homes etc.). In addition, differential survival by race and ethnicity may be particularly large.

16 The health of seniors may still be affected by collapsing house prices. For example, because staffing in nursing homes moves counter-cyclically, seniors over 65 in nursing homes may receive different care as a result of the recession (Stevens et al., 2015). This population may also depend on their accumulated housing wealth to fund transitions late in life (e.g., wealth transfers, funding nursing home stays), or may need to support family members who lost their homes or large amounts of wealth as a result of the collapse.

17 Medicare eligibility means that this group does not depend solely on employer sponsored health insurance.
} 


\section{Why do House Price Changes Matter?}

House price changes might affect mental health in two major ways. First, they could be associated with individual hardship. For example, in areas where house prices fell more, people are more likely to lose their jobs or be underwater in their mortgages. Second, house prices could affect the broader economic or social conditions of everyone in an area. For example, tax revenues decline with house price declines, which may result in reduced public services. Similarly, anxiety about economic losses may affect mental health, even if household members retain their homes or remain employed.

To shed light on potential mechanisms driving variation in mental health impacts, we examine the extent to which house prices were correlated with financial and social hardship at the individual level. Appendix Table D.1 shows the mechanisms we consider. We look at individual-level economic factors (such as the fraction of housing wealth lost), social factors (such as feelings of isolation), and indicators of stress (such as the perceived likelihood of job loss). We also consider financial strain at the family level and socioeconomic changes to one's neighborhood environment, such as perceived changes to neighborhood safety and the number of local vacant properties.

Appendix Table D.2 shows that only a small subset of the mechanisms we test for are correlated with changes in the house price index. All of these are financial in nature, such as the share of housing wealth lost and the value of housing equity. In contrast, social measures such as money owed, difficulty paying monthly bills, and the perceived possibility of losing a job are not associated with house price changes.

We then estimate models for mental health status including controls for these mediator variables. If house price declines affect mental health because they are related to stress, for example, including the stress measures in the regression should reduce the estimated impact of house price declines on mental health. In general, many of the mediator variables predict mental health, including variables such as foreclosure, stress, and trouble paying monthly 
bills. However, most of these variables related to mental health are not correlated with house price changes. For the subset of mediators that are correlated with area house price changes, Appendix Table D.3 shows no changes in the coefficient on the house price index across models in which they are added to the right-hand side of equation (1). Overall, these results suggest that house prices matter for mental health beyond the potential mediators we can identify in the HRS. Further research is needed to explore why that might be.

\section{Conclusion}

The Great Recession was the biggest economic downturn since the Great Depression, producing effects felt throughout the US economy for many years. Our paper examines the impact of the Great Recession on three sets of health outcomes that emphasize mental health: symptoms of depression; chronic pain severity and functional limitations; and the use of medications to treat sleep, depression, and/or anxiety.

We identify the effect of the Great Recession using cross-area data on house prices, exploiting the large geographic variation in the magnitude of the decline in house prices that began in late 2006. Our assumption is that if the house price collapse in the Great Recession affected mental health, variation in mental health outcomes should mirror variation in house prices.

Overall, we find that the mental health impacts of the Great Recession were heterogeneous and unequally distributed. We find that mental health was not impacted on average, either for older adults aged 51 to 61 or for seniors aged 65 to 74 . Instead, we find that falling house prices worsened only the mental health of those in economically vulnerable households and that these effects varied by race and health condition. Black and other non-white homeowners show signs of worsened mental health across most measures. White homeowners did not exhibit worsened mental health but became more likely to take medication. We find no evidence that the mental health of Hispanic homeowners in our sample was affected. Future work should examine the underlying reasons for these differences, as they may underscore 
disparities in treatment or social resilience ${ }^{18}$ that may would have important implications for health equity.

Because these economically vulnerable households were already in worse health at baseline, our results indicate that the Great Recession widened existing health disparities between racial and economic groups. The implications of these findings are troubling for academics and policymakers seeking to improve health equity.

Despite testing a wide range of potential mechanisms at the individual, family, and neighborhood level, we are not able to clearly identify the pathway through which house prices affected the mental health of populations. It is therefore likely that the mechanisms underlying mental health effects extend beyond housing wealth or foreclosures. As the mental health of seniors aged 65 to 74 was not affected, it is possible that mental health effects are mediated through features of the labor market or have smaller impacts among seniors because of reasonably generous social insurance programs available to this age group. This latter explanation is consistent with other work that finds that large economic shocks produce no negative effects on mental health in countries with comprehensive social insurance programs (Cesarini et al., 2016; Lindqvist et al., 2020). Understanding the reasons for these disparate impacts, particularly across racial groups, should be a central focus for future research.

\footnotetext{
18 For example, these differences could be the result of unequal prescribing behavior for patients according to patient race, but they may also be the result of different care-seeking behavior by distinct patient groups.
} 


\section{References}

Ben Barr, David Taylor-Robinson, Alex Scott-Samuel, Martin McKee, and David Stuckler. Suicides associated with the 2008-10 economic recession in england: time trend analysis. BMJ (Online), 345(aug13 2):22-e5142, 2012. ISSN 0959-8138.

Alexander Bogin, William Doerner, and William Larson. Local house price dynamics: New indices and stylized facts. Real Estate Economics, 47(2):365-398, 2019.

Bureau of Labor Statistics. The recession of 2007 - 2009, 2012. URL https://www.bls. gov/spotlight/2012/recession/pdf/recession_bls_spotlight.pdf.

Anne Case and Angus Deaton. Rising morbidity and mortality in midlife among white nonhispanic americans in the 21st century. Proceedings of the National Academy of Sciences, 112(49):15078-15083, 2015.

David Cesarini, Erik Lindqvist, Robert Östling, and Björn Wallace. Wealth, health, and child development: Evidence from administrative data on swedish lottery players. The Quarterly Journal of Economics, 131(2):687-738, 2016.

Kerwin Kofi Charles and Philip DeCicca. Local labor market fluctuations and health: is there a connection and for whom? Journal of health economics, 27(6):1532-1550, 2008.

Somnath Chatterji, Julie Byles, David Cutler, Teresa Seeman, and Emese Verdes. Health, functioning, and disability in older adults - present status and future implications. The lancet, 385(9967):563-575, 2015.

Cornelius Christian, Lukas Hensel, and Christopher Roth. Income shocks and suicides: Causal evidence from indonesia. Review of Economics and Statistics, 101(5):905-920, 2019.

Janet Currie and Erdal Tekin. Is there a link between foreclosure and health? American Economic Journal: Economic Policy, 7(1):63-94, 2015. 
Janet Currie, Valentina Duque, and Irwin Garfinkel. The great recession and mothers' health. The Economic Journal, 125(588):F311-F346, 2015.

Sheldon Danziger, Koji Chavez, and Erin Cumberworth. Poverty and the great recession. In Social Stratification, pages 357-364. Routledge, 2018.

Janelle Downing. The health effects of the foreclosure crisis and unaffordable housing: a systematic review and explanation of evidence. Social Science $\&$ Medicine, 162:88-96, 2016.

Ingrid Gould Ellen and Samuel Dastrup. Housing and the great recession. The Russell Sage Foundation and The Stanford Center on Poverty and Inequality, 2012.

Richard G Frank and Sherry A Glied. Employing people with mental illness in the 21st century: Labor market changes and policy challenges. 2018.

Diana Frasquilho, Margarida Gaspar Matos, Ferdinand Salonna, Diogo Guerreiro, Claudia C Storti, Tania Gaspar, and Jose M Caldas-de Almeida. Mental health outcomes in times of economic recession: a systematic literature review. BMC public health, 16(1):115-115, 2016. ISSN 1471-2458.

Joseph Gyourko and Peter Linneman. The changing influences of education, income, family structure, and race on homeownership by age over time. Journal of Housing Research, pages $1-25,1997$.

Joseph Gyourko and Raven Molloy. Regulation and housing supply. In Handbook of regional and urban economics, volume 5, pages 1289-1337. Elsevier, 2015.

Adam Hadi. Construction employment peaks before the recession and falls sharply throughout it. Monthly Lab. Rev., 134:24, 2011.

Matthew Hall, Kyle Crowder, and Amy Spring. Variations in housing foreclosures by race 
and place, 2005-2012. The ANNALS of the American Academy of Political and Social Science, 660(1):217-237, 2015.

Garth Heutel and Christopher J Ruhm. Air pollution and procyclical mortality. Journal of the Association of Environmental and Resource Economists, 3(3):667-706, 2016.

Hilary Hoynes, Douglas L Miller, and Jessamyn Schaller. Who suffers during recessions? Journal of Economic perspectives, 26(3):27-48, 2012.

Michael D Hurd, Pierre-Carl Michaud, Susann Rohwedder, et al. The lifetime risk of nursing home use. Discoveries in the Economics of Aging, pages 81-109, 2014.

Frank J Kohout, Lisa F Berkman, Denis A Evans, and Joan Cornoni-Huntley. Two shorter forms of the ces-d depression symptoms index. Journal of aging and health, 5(2):179-193, 1993.

James Krieger and Donna L Higgins. Housing and health: time again for public health action. American journal of public health, 92(5):758-768, 2002.

Andreas Kuhn, Rafael Lalive, and Josef Zweimüller. The public health costs of job loss. Journal of health economics, 28(6):1099-1115, 2009.

Erik Lindqvist, Robert Östling, and David Cesarini. Long-run effects of lottery wealth on psychological well-being. The Review of Economic Studies, 87(6):2703-2726, 2020.

Alison Luciano, Joanne Nicholson, and Ellen Meara. The economic status of parents with serious mental illness in the united states. Psychiatric rehabilitation journal, 37(3):242, 2014.

Melissa Powell McInerney and Jennifer M Mellor. State unemployment in recessions during 1991-2009 was linked to faster growth in medicare spending. Health Affairs, 31(11):2464$2473,2012$. 
Signe-Mary McKernan, Caroline Ratcliffe, Eugene Steuerle, and Sisi Zhang. Disparities in wealth accumulation and loss from the great recession and beyond. American Economic Review, 104(5):240-44, 2014.

Atif Mian and Amir Sufi. House of debt: How they (and you) caused the Great Recession, and how we can prevent it from happening again. University of Chicago Press, 2015.

Mark J Millan, Yves Agid, Martin Brüne, Edward T Bullmore, Cameron S Carter, Nicola S Clayton, Richard Connor, Sabrina Davis, Bill Deakin, Robert J DeRubeis, et al. Cognitive dysfunction in psychiatric disorders: characteristics, causes and the quest for improved therapy. Nature reviews Drug discovery, 11(2):141-168, 2012.

Douglas L Miller, Marianne E Page, Ann Huff Stevens, and Mateusz Filipski. Why are recessions good for your health? American Economic Review, 99(2):122-27, 2009.

Arijit Nandi, Marta R Prescott, Magdalena Cerdá, David Vlahov, Kenneth J Tardiff, and Sandro Galea. Economic conditions and suicide rates in new york city. American journal of epidemiology, 175(6):527-535, 2012.

Eric Neumayer. Recessions lower (some) mortality rates:: evidence from germany. Social science $\mathscr{E}$ medicine, 58(6):1037-1047, 2004.

Fabian T Pfeffer, Sheldon Danziger, and Robert F Schoeni. Wealth disparities before and after the great recession. The ANNALS of the American Academy of Political and Social Science, 650(1):98-123, 2013.

Lenore Sawyer Radloff. The ces-d scale: A self-report depression scale for research in the general population. Applied psychological measurement, 1(3):385-401, 1977.

Matthew Ridley, Gautam Rao, Frank Schilbach, and Vikram Patel. Poverty, depression, and anxiety: Causal evidence and mechanisms. Science, 370(6522):eaay0214, 2020. 
Richard Rothstein. The color of law : a forgotten history of how our government segregated America. Democracy and urban landscapes. Liveright Publishing Corporation, a division of W.W. Norton \& Company, New York ; London, first edition. edition, 2017. ISBN 9781631492853.

Jacob S Rugh and Douglas S Massey. Racial segregation and the american foreclosure crisis. American sociological review, 75(5):629-651, 2010. ISSN 0003-1224.

Christopher J Ruhm. Are recessions good for your health? The Quarterly journal of economics, 115(2):617-650, 2000. ISSN 0033-5533.

Christopher J Ruhm. Good times make you sick. Journal of health economics, 22(4):637-658, 2003. ISSN 0167-6296.

Christopher J Ruhm. Healthy living in hard times. Journal of health economics, 24(2): 341-363, 2005. ISSN 0167-6296.

Christopher J Ruhm. Recessions, healthy no more? Journal of health economics, 42:17-28, 2015. ISSN 0167-6296.

Gregory E Simon, Michael VonKorff, Marco Piccinelli, Claudio Fullerton, and Johan Ormel. An international study of the relation between somatic symptoms and depression. The New England Journal of Medicine, 341(18):1329-1335, 1999. ISSN 0028-4793.

Ann H Stevens, Douglas L Miller, Marianne E Page, and Mateusz Filipski. The best of times, the worst of times: understanding pro-cyclical mortality. American Economic Journal: Economic Policy, 7(4):279-311, 2015.

David Stuckler, Sanjay Basu, Marc Suhrcke, Adam Coutts, and Martin McKee. The public health effect of economic crises and alternative policy responses in europe: an empirical analysis. The Lancet, 374(9686):315-323, 2009. 
Carolyn B Swope and Diana Hernández. Housing as a determinant of health equity: A conceptual model. Social Science \&5 Medicine, 243:112571, 2019.

José A Tapia Granados. Recessions and mortality in spain, 1980-1997. European Journal of Population/Revue européenne de Démographie, 21(4):393-422, 2005.

José A Tapia Granados and Edward L Ionides. Population health and the economy: Mortality and the great recession in europe. Health economics, 26(12):e219-e235, 2017.

José A Tapia Granados and Ana V Diez Roux. Life and death during the great depression. Proceedings of the national academy of sciences, 106(41):17290-17295, 2009.

José A Tapia Granados, James S House, Edward L Ionides, Sarah Burgard, and Robert S Schoeni. Individual joblessness, contextual unemployment, and mortality risk. American journal of epidemiology, 180(3):280-287, 2014.

Madhukar H Trivedi. The link between depression and physical symptoms. Primary care companion to the Journal of clinical psychiatry, 6(suppl 1):12, 2004.

Gemma Vilagut, Carlos G Forero, Gabriela Barbaglia, and Jordi Alonso. Screening for depression in the general population with the center for epidemiologic studies depression (ces-d): a systematic review with meta-analysis. PloS one, 11(5):e0155431, 2016.

Tansel Yilmazer, Patryk Babiarz, and Fen Liu. The impact of diminished housing wealth on health in the united states: Evidence from the great recession. Social science $\mathbb{E}$ medicine, 130:234-241, 2015. 
Figure 1: Mental Health Trends among Pre-Retirement Adults by Magnitude of the House Price Decline ${ }^{\dagger}, 2000$ to 2016
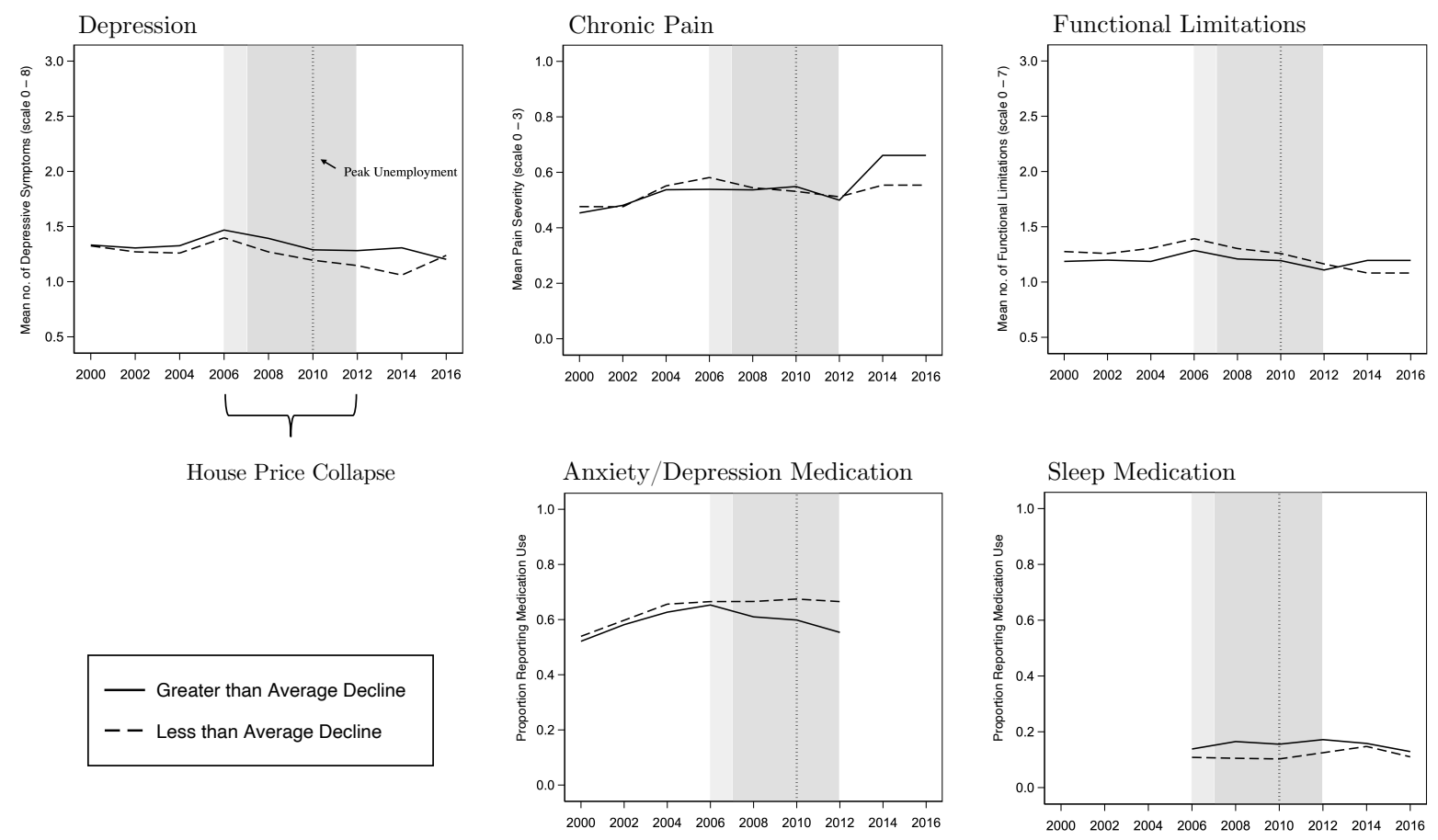

$\dagger$ The magnitude of the house price decline refers to the difference in house prices between 2006 and 2012. House prices are measured at the core-based statistical area (CBSA) level. CBSAs with greater than average declines are those where house prices fell more than average between 2006 and 2012. CBSAs with less than average declines are where house prices fell less than average over the same time period. 
Figure 2: Racial and Ethnic Variability in Depression, Chronic Pain, and Functional Limitations Trends by Magnitude of the House Price Decline ${ }^{\dagger}, 2000$ to 2016

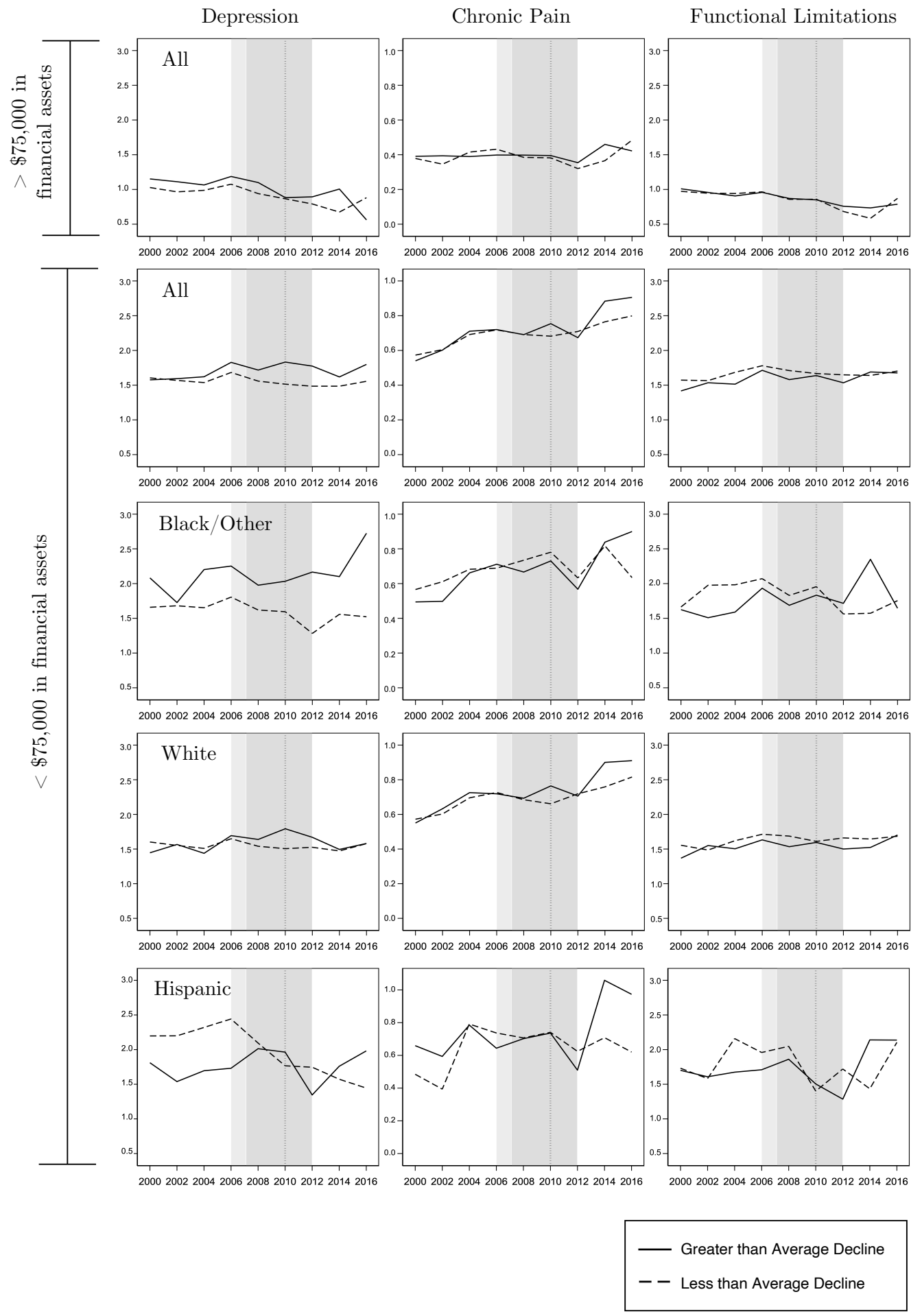

$\dagger$ The magnitude of the house price decline refers to the difference in house prices between 2006 and 2012. House prices are measured at the core-based statistical area (CBSA) level. CBSAs with greater than average declines are those where house prices fell more than average between 2006 and 2012. CBSAs with less than average declines are where house prices fell less than average over the same time period. 
Figure 3: Racial and Ethnic Variability in Medication Trends by Magnitude of the House Price Decline ${ }^{\dagger}, 2000$ to 2016

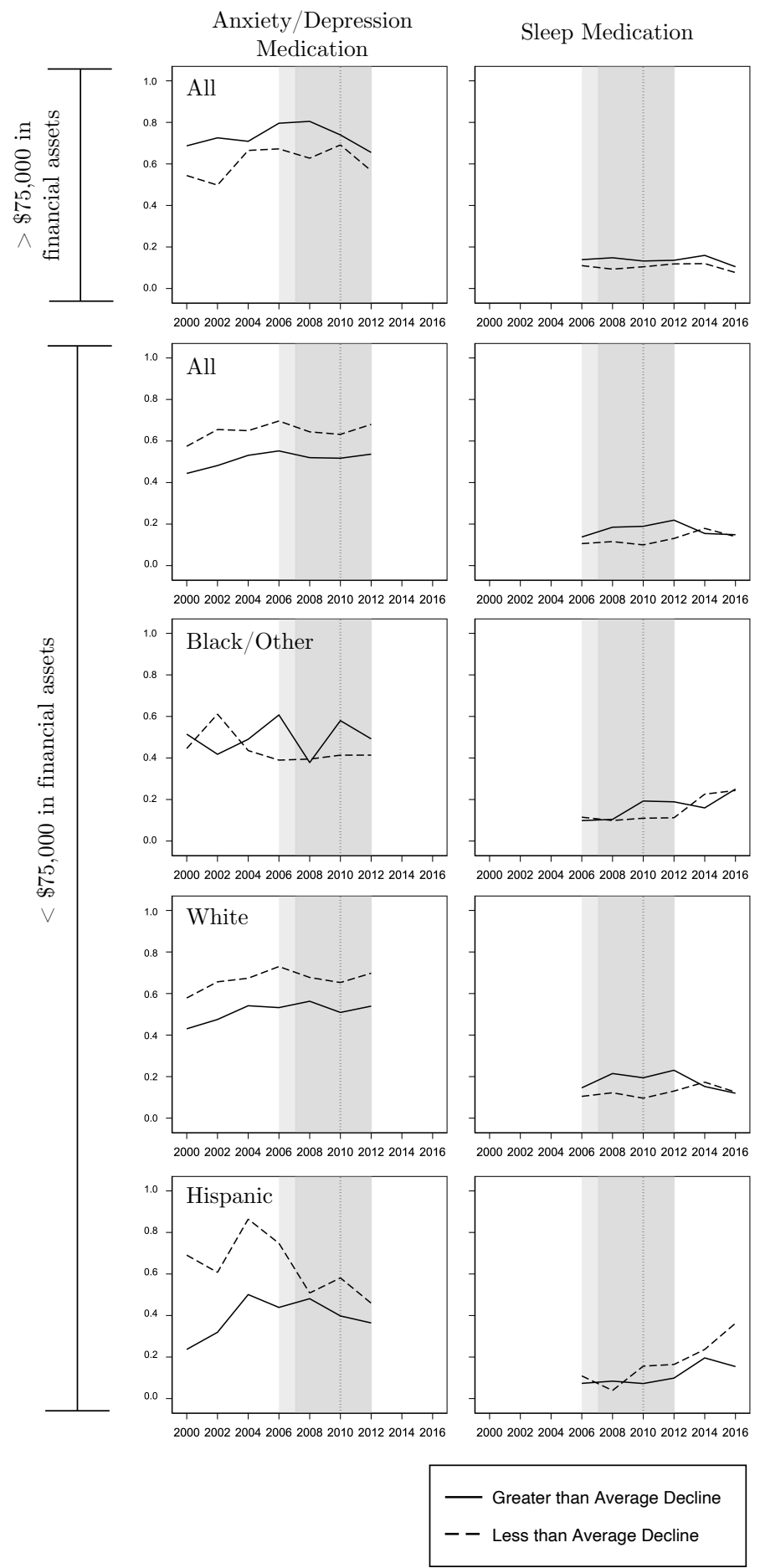

$\dagger$ The magnitude of the house price decline refers to the difference in house prices between 2006 and 2012. House prices are measured at the core-based statistical area (CBSA) level. CBSAs with greater than average declines are those where house prices fell more than average between 2006 and 2012. CBSAs with less than average declines are where house prices fell less than average over the same time period. 
Figure 4: Robustness of Table 3 Panel 1 Estimates, Homeowners with Few Financial Assets
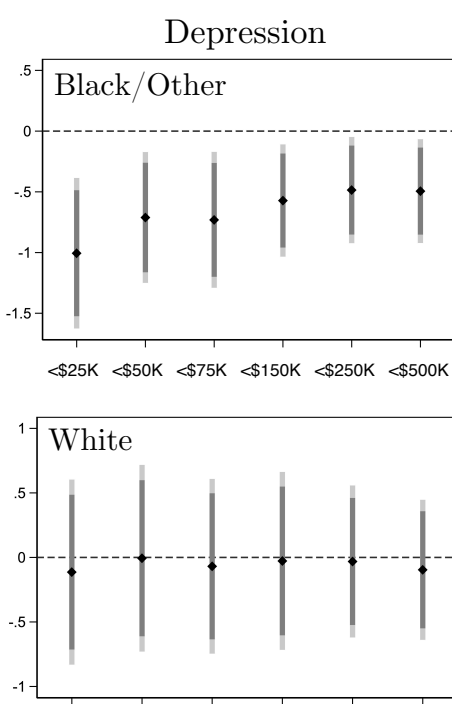

$<\$ 25 \mathrm{~K}<\$ 50 \mathrm{~K}<\$ 75 \mathrm{~K}<\$ 150 \mathrm{~K}<\$ 250 \mathrm{~K}<\$ 500 \mathrm{~K}$

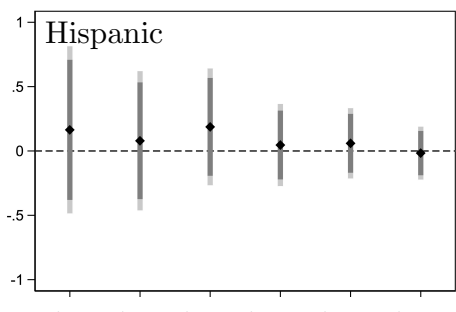

$<25 K<\$ 50 K<\$ 75 K<\$ 150 K<\$ 250 K<\$ 500 K$
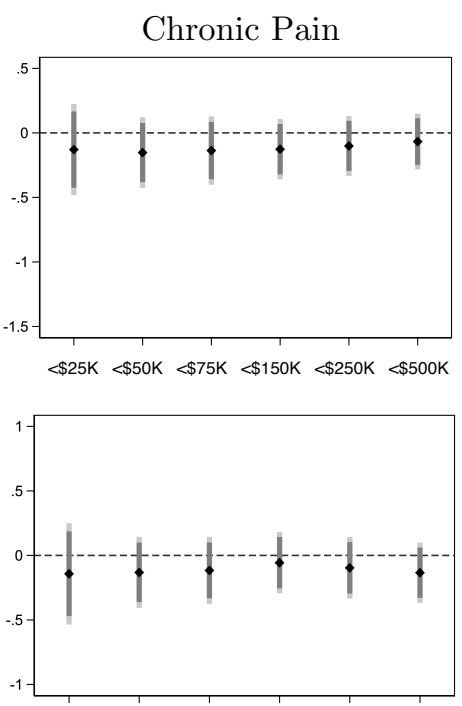

$<\$ 25 \mathrm{~K}<\$ 50 \mathrm{~K}<\$ 75 \mathrm{~K}<\$ 150 \mathrm{~K}<\$ 250 \mathrm{~K}<\$ 500 \mathrm{~K}$

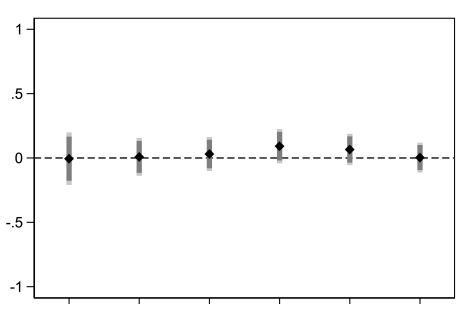

$<\$ 25 \mathrm{~K}<\$ 50 \mathrm{~K}<\$ 75 \mathrm{~K}<\$ 150 \mathrm{~K}<\$ 250 \mathrm{~K}<\$ 500 \mathrm{~K}$
Functional Limitations
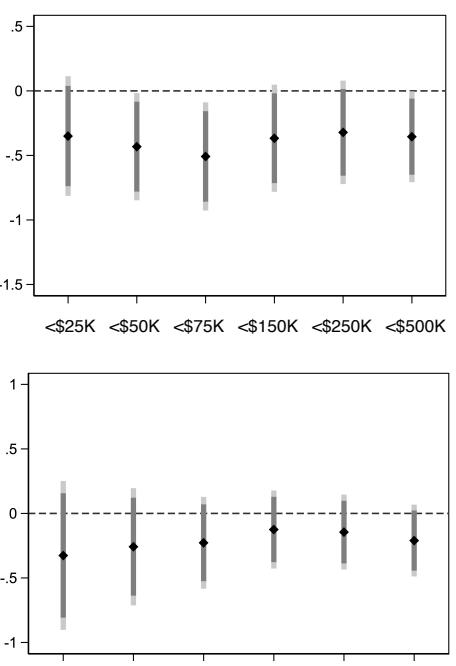

$<\$ 25 \mathrm{~K}<\$ 50 \mathrm{~K}<\$ 75 \mathrm{~K}<\$ 150 \mathrm{~K}<\$ 250 \mathrm{~K}<\$ 500 \mathrm{~K}$

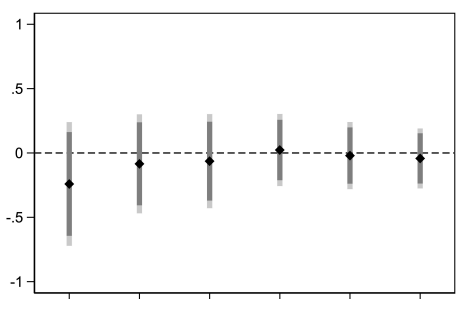

$<\$ 25 \mathrm{~K}<\$ 50 \mathrm{~K}<\$ 75 \mathrm{~K}<\$ 150 \mathrm{~K}<\$ 250 \mathrm{~K}<\$ 500 \mathrm{~K}$

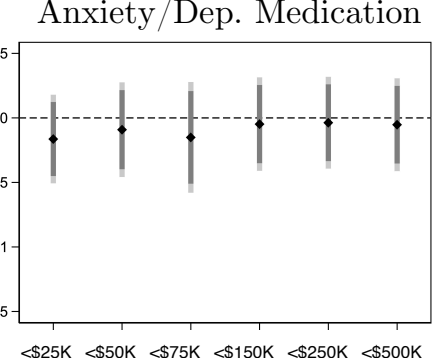

$<\$ 25 K<\$ 50 K<\$ 75 K<\$ 150 K<\$ 250 K<\$ 500 K$
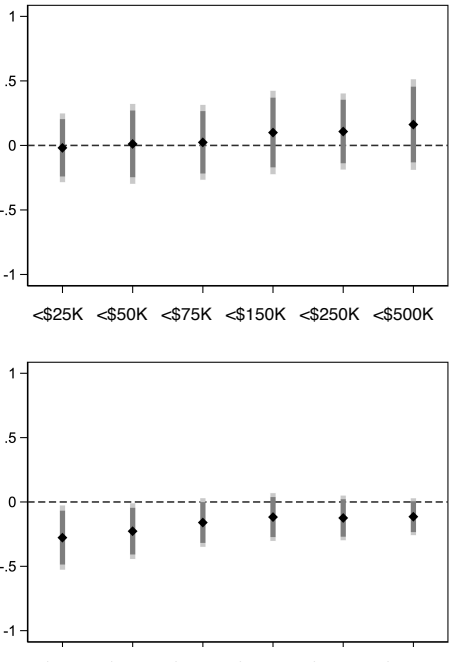

$\$ 25 K<\$ 50 K<\$ 75 K<\$ 150 K<\$ 250 K<\$ 500 K$
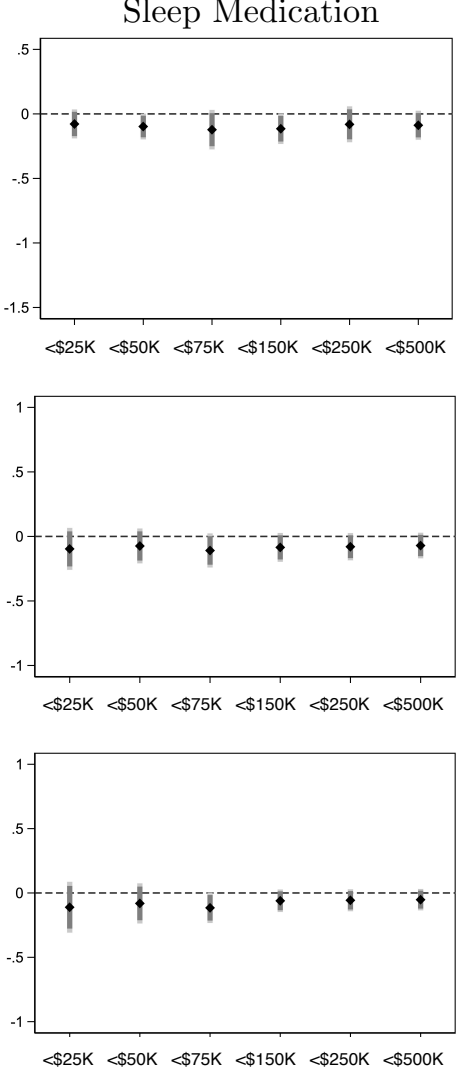

Bars show the coefficient on the house price index from equation (1) run on the subgroup in each row; dots are point estimates and bars are confidence intervals (dark bar: 95\% CI, light bar: 99\% CI). Rows correspond to the last three rows of panel 1 in Table 3 where the definition of financial assets are varied in 10 percentile increments from roughly the 30th to the 80th percentiles. 
Table 1: Effect of House Prices on Older Adult Mental Health

\begin{tabular}{|c|c|c|c|c|c|}
\hline & (1) & (2) & (3) & (4) & (5) \\
\hline & Depression & $\begin{array}{l}\text { Chronic } \\
\text { Pain }\end{array}$ & $\begin{array}{l}\text { Functional } \\
\text { Limitations }\end{array}$ & $\begin{array}{c}\text { Anxiety/ } \\
\text { Depression } \\
\text { Medications }\end{array}$ & $\begin{array}{c}\text { Sleep } \\
\text { Medications }\end{array}$ \\
\hline \multicolumn{6}{|l|}{ Full Sample } \\
\hline House Price Index & $\begin{array}{l}-0.067 \\
(0.083)\end{array}$ & $\begin{array}{l}-0.031 \\
(0.050)\end{array}$ & $\begin{array}{l}-0.045 \\
(0.085)\end{array}$ & $\begin{array}{l}-0.035 \\
(0.057)\end{array}$ & $\begin{array}{l}-0.038 \\
(0.030)\end{array}$ \\
\hline Not in labor force & $\begin{array}{c}0.259 * * * \\
(0.062)\end{array}$ & $\begin{array}{c}0.027 \\
(0.027)\end{array}$ & $\begin{array}{c}0.285^{* * *} \\
(0.045)\end{array}$ & $\begin{array}{c}0.021 \\
(0.042)\end{array}$ & $\begin{array}{l}-0.001 \\
(0.018)\end{array}$ \\
\hline Widowed & $\begin{array}{c}0.796 * * * \\
(0.176)\end{array}$ & $\begin{array}{c}0.055 \\
(0.069)\end{array}$ & $\begin{array}{c}0.014 \\
(0.096)\end{array}$ & $\begin{array}{l}-0.030 \\
(0.103)\end{array}$ & $\begin{array}{c}0.024 \\
(0.053)\end{array}$ \\
\hline Cancer diagnosis & $\begin{array}{c}0.202 \\
(0.153)\end{array}$ & $\begin{array}{l}0.133^{*} \\
(0.070)\end{array}$ & $\begin{array}{c}0.322 * * * \\
(0.122)\end{array}$ & $\begin{array}{c}0.044 \\
(0.085)\end{array}$ & $\begin{array}{l}-0.006 \\
(0.035)\end{array}$ \\
\hline Observations & 26321 & 27835 & 27887 & 4542 & 9701 \\
\hline $\begin{array}{l}\text { Number of clusters } \\
\mathrm{R}^{2}\end{array}$ & $\begin{array}{l}356 \\
0.69\end{array}$ & $\begin{array}{l}359 \\
0.68\end{array}$ & $\begin{array}{l}359 \\
0.78\end{array}$ & $\begin{array}{l}218 \\
0.75\end{array}$ & $\begin{array}{l}244 \\
0.77\end{array}$ \\
\hline \multicolumn{6}{|l|}{ Homeowners } \\
\hline House Price Index & $\begin{array}{l}-0.088 \\
(0.081)\end{array}$ & $\begin{array}{l}-0.042 \\
(0.049)\end{array}$ & $\begin{array}{l}-0.080 \\
(0.087)\end{array}$ & $\begin{array}{l}-0.056 \\
(0.060)\end{array}$ & $\begin{array}{l}-0.039 \\
(0.031)\end{array}$ \\
\hline Not in labor force & $\begin{array}{c}0.271 * * * \\
(0.064)\end{array}$ & $\begin{array}{c}0.015 \\
(0.028)\end{array}$ & $\begin{array}{c}0.279 * * * \\
(0.047)\end{array}$ & $\begin{array}{c}0.025 \\
(0.043)\end{array}$ & $\begin{array}{l}-0.002 \\
(0.019)\end{array}$ \\
\hline Widowed & $\begin{array}{c}0.804 * * * \\
(0.173)\end{array}$ & $\begin{array}{c}0.057 \\
(0.076)\end{array}$ & $\begin{array}{c}0.011 \\
(0.106)\end{array}$ & $\begin{array}{l}-0.024 \\
(0.109)\end{array}$ & $\begin{array}{c}0.002 \\
(0.050)\end{array}$ \\
\hline Cancer diagnosis & $\begin{array}{c}0.216 \\
(0.158)\end{array}$ & $\begin{array}{r}0.144 * * \\
(0.072)\end{array}$ & $\begin{array}{c}0.358 * * * \\
(0.123)\end{array}$ & $\begin{array}{c}0.088 \\
(0.092)\end{array}$ & $\begin{array}{l}-0.004 \\
(0.036)\end{array}$ \\
\hline Observations & 24841 & 26285 & 26332 & 4212 & 9379 \\
\hline Number of clusters & 334 & 337 & 337 & 208 & 232 \\
\hline $\mathrm{R}^{2}$ & 0.68 & 0.68 & 0.78 & 0.74 & 0.77 \\
\hline \multicolumn{6}{|l|}{ Homeowners with one home } \\
\hline House Price Index & $\begin{array}{l}-0.090 \\
(0.096)\end{array}$ & $\begin{array}{l}-0.020 \\
(0.058)\end{array}$ & $\begin{array}{l}-0.113 \\
(0.100)\end{array}$ & $\begin{array}{l}-0.107 \\
(0.072)\end{array}$ & $\begin{array}{l}-0.044 \\
(0.037)\end{array}$ \\
\hline Not in labor force & $\begin{array}{c}0.287 * * * \\
(0.069)\end{array}$ & $\begin{array}{c}0.016 \\
(0.031)\end{array}$ & $\begin{array}{c}0.320^{* * *} \\
(0.054)\end{array}$ & $\begin{array}{c}0.032 \\
(0.053)\end{array}$ & $\begin{array}{c}0.003 \\
(0.019)\end{array}$ \\
\hline Widowed & $\begin{array}{c}0.809^{* * *} \\
(0.189)\end{array}$ & $\begin{array}{c}0.048 \\
(0.095)\end{array}$ & $\begin{array}{c}0.019 \\
(0.121)\end{array}$ & $\begin{array}{l}-0.093 \\
(0.092)\end{array}$ & $\begin{array}{l}-0.014 \\
(0.060)\end{array}$ \\
\hline Cancer diagnosis & $\begin{array}{c}0.191 \\
(0.180)\end{array}$ & $\begin{array}{c}0.103 \\
(0.081)\end{array}$ & $\begin{array}{c}0.431 * * * \\
(0.145)\end{array}$ & $\begin{array}{c}0.029 \\
(0.115)\end{array}$ & $\begin{array}{c}0.007 \\
(0.045)\end{array}$ \\
\hline Observations & 21381 & 22659 & 22698 & 3651 & 7685 \\
\hline Number of clusters & 330 & 334 & 334 & 204 & 216 \\
\hline $\mathrm{R}^{2}$ & 0.70 & 0.69 & 0.79 & 0.75 & 0.79 \\
\hline
\end{tabular}




\begin{tabular}{lccccc}
\hline Non homeowners & & & & & \\
House Price Index & 0.328 & 0.128 & 0.508 & 0.306 & 0.045 \\
& $(0.507)$ & $(0.194)$ & $(0.313)$ & $(0.197)$ & $(0.240)$ \\
Not in labor force & -0.021 & $0.235^{* *}$ & 0.387 & -0.036 & 0.135 \\
& $(0.322)$ & $(0.117)$ & $(0.248)$ & $(0.160)$ & $(0.150)$ \\
Widowed & $0.899^{*}$ & 0.043 & 0.059 & -0.285 & 0.142 \\
& $(0.541)$ & $(0.155)$ & $(0.234)$ & $(0.351)$ & $(0.362)$ \\
Cancer & -0.236 & -0.100 & -0.418 & -0.223 & -0.072 \\
Observations & $(0.724)$ & $(0.454)$ & $(0.836)$ & $(0.153)$ & $(0.123)$ \\
Number of clusters & 1480 & 1550 & 1555 & 330 & 322 \\
$\mathrm{R}^{2}$ & 134 & 136 & 136 & 76 & 74 \\
& 0.74 & 0.70 & 0.83 & 0.80 & 0.80 \\
\hline
\end{tabular}

Note: All regressions include individual and year effects and are weighted to represent our target population: a nationally representative sample of 51- to 61-year-old adults. Standard errors are clustered by core-based statistical area. ${ }^{*} \mathrm{p}<0.10,{ }^{* *} \mathrm{p}<0.05,{ }^{* * *} \mathrm{p}<0.01$. Reference categories: full time employment, married, no cancer diagnosis. 
Table 2: Additional Effect of House Price Changes by Race/Ethnicity, Education, Financial Assets, and Tenure

\begin{tabular}{lccccc}
\hline & $(1)$ & $(2)$ & $(3)$ & $(4)$ & $(5)$ \\
& Depression & $\begin{array}{c}\text { Chronic } \\
\text { pain }\end{array}$ & $\begin{array}{c}\text { Functional } \\
\text { Limitations }\end{array}$ & $\begin{array}{c}\text { Anxiety/ } \\
\text { Depression } \\
\text { Medications }\end{array}$ & $\begin{array}{c}\text { Sleep } \\
\text { Medications }\end{array}$ \\
\hline House Price Index & 0.062 & -0.045 & $-0.230^{*}$ & -0.027 & 0.023 \\
& $(0.123)$ & $(0.067)$ & $(0.122)$ & $(0.108)$ & $(0.058)$ \\
x Black non-Hispanic & -0.248 & 0.000 & -0.051 & -0.068 & 0.086 \\
& $(0.329)$ & $(0.092)$ & $(0.244)$ & $(0.132)$ & $(0.058)$ \\
x Other non-Hispanic & -0.304 & 0.029 & 0.057 & -0.000 & 0.003 \\
& $(0.216)$ & $(0.103)$ & $(0.152)$ & $(0.136)$ & $(0.052)$ \\
x Hispanic & 0.251 & -0.048 & 0.158 & 0.053 & $0.058^{*}$ \\
& $(0.176)$ & $(0.063)$ & $(0.131)$ & $(0.120)$ & $(0.034)$ \\
x C College degree & -0.027 & 0.009 & 0.155 & 0.027 & -0.043 \\
& $(0.079)$ & $(0.052)$ & $(0.096)$ & $(0.086)$ & $(0.051)$ \\
x $<$ \$s5,000 in financial & -0.007 & 0.009 & -0.036 & 0.059 & $-0.045^{*}$ \\
assets & $(0.146)$ & $(0.046)$ & $(0.074)$ & $(0.056)$ & $(0.025)$ \\
x Recent homeowner ${ }^{\dagger}$ & -0.730 & 0.073 & 0.428 & 0.099 & 0.478 \\
& $(0.572)$ & $(0.168)$ & $(0.415)$ & $(0.281)$ & $(0.407)$ \\
x Recently sold & 0.093 & 0.012 & 0.642 & -0.088 & -0.401 \\
& $(0.571)$ & $(0.158)$ & $(0.484)$ & $(0.232)$ & $(0.249)$ \\
x Not homeowner & 0.177 & 0.092 & $0.561 * *$ & -0.053 & 0.126 \\
Observations & $(0.228)$ & $(0.119)$ & $(0.220)$ & $(0.125)$ & $(0.172)$ \\
No. Clusters & 26321 & 27835 & 27887 & 4542 & 9701 \\
$\mathrm{R}^{2}$ & 356 & 359 & 359 & 218 & 244 \\
& 0.69 & 0.68 & 0.78 & 0.75 & 0.77 \\
\hline
\end{tabular}

Note: All regressions include individual and year fixed effects and are weighted to represent our target population: a nationally representative sample of 51- to 61-year-old adults. Standard errors are clustered by core-based statistical area. ${ }^{*} \mathrm{p}<0.10,{ }^{* *} \mathrm{p}<0.05,{ }^{* * *} \mathrm{p}<0.01$. $\dagger$ Recent homeowners are those that bought a home within two to four years of the decline (i.e. between 2002 and 2004). $\ddagger$ Recent sellers are those who sold a home within two to four years of the decline (i.e. between 2002 and 2004). 
Table 3: Heterogeneous Effects of the House Price Decline by Financial Assets, Race/Ethnicity, and Education

\begin{tabular}{|c|c|c|c|c|c|c|}
\hline & & (1) & (2) & (3) & (4) & (5) \\
\hline & Observations & Depression & $\begin{array}{l}\text { Pain } \\
\text { Severity }\end{array}$ & $\begin{array}{l}\text { Functional } \\
\text { Limitations }\end{array}$ & $\begin{array}{l}\text { Anxiety / } \\
\text { Depression } \\
\text { Medication }\end{array}$ & $\begin{array}{c}\text { Sleep } \\
\text { Medication }\end{array}$ \\
\hline \multicolumn{7}{|c|}{ Panel 1: $<\$ 75,000$ in Financial Assets } \\
\hline$\geq \$ 75,000$ & 12,937 & $\begin{array}{l}-0.165 \\
(0.142)\end{array}$ & $\begin{array}{l}-0.087 \\
(0.062)\end{array}$ & $\begin{array}{l}-0.021 \\
(0.114)\end{array}$ & $\begin{array}{c}0.023 \\
(0.147)\end{array}$ & $\begin{array}{l}-0.008 \\
(0.051)\end{array}$ \\
\hline$<\$ 75,000$, all & 14,950 & $\begin{array}{l}-0.034 \\
(0.207)\end{array}$ & $\begin{array}{l}-0.010 \\
(0.070)\end{array}$ & $\begin{array}{l}-0.161 \\
(0.140)\end{array}$ & $\begin{array}{l}-0.136 \\
(0.095)\end{array}$ & $\begin{array}{c}-0.108^{* *} \\
(0.047)\end{array}$ \\
\hline Black / Other Races & 4,745 & $\begin{array}{c}-0.731^{* *} \\
(0.283)\end{array}$ & $\begin{array}{l}-0.137 \\
(0.134)\end{array}$ & $\begin{array}{c}-0.508^{* *} \\
(0.212)\end{array}$ & $\begin{array}{l}-0.151 \\
(0.216)\end{array}$ & $\begin{array}{l}-0.122 \\
(0.077)\end{array}$ \\
\hline White & 10,205 & $\begin{array}{c}0.187 \\
(0.230)\end{array}$ & $\begin{array}{c}0.031 \\
(0.067)\end{array}$ & $\begin{array}{l}-0.064 \\
(0.186)\end{array}$ & $\begin{array}{l}-0.160^{*} \\
(0.096)\end{array}$ & $\begin{array}{l}-0.115^{*} \\
(0.060)\end{array}$ \\
\hline Hispanic & 2,521 & $\begin{array}{l}-0.069 \\
(0.340)\end{array}$ & $\begin{array}{l}-0.116 \\
(0.130)\end{array}$ & $\begin{array}{l}-0.227 \\
(0.179)\end{array}$ & $\begin{array}{c}0.024 \\
(0.144)\end{array}$ & $\begin{array}{l}-0.109 \\
(0.066)\end{array}$ \\
\hline \multicolumn{7}{|l|}{ Panel 2: < College Degree } \\
\hline$\geq$ College Degree & 7,588 & $\begin{array}{c}-0.252^{* *} \\
(0.120)\end{array}$ & $\begin{array}{l}-0.019 \\
(0.057)\end{array}$ & $\begin{array}{l}-0.109 \\
(0.092)\end{array}$ & $\begin{array}{l}-0.126 \\
(0.105)\end{array}$ & $\begin{array}{c}0.006 \\
(0.052)\end{array}$ \\
\hline$<$ College Degree, all & 20,299 & $\begin{array}{l}-0.027 \\
(0.103)\end{array}$ & $\begin{array}{l}-0.048 \\
(0.060)\end{array}$ & $\begin{array}{l}-0.058 \\
(0.107)\end{array}$ & $\begin{array}{l}-0.034 \\
(0.073)\end{array}$ & $\begin{array}{l}-0.063 \\
(0.042)\end{array}$ \\
\hline Black / Other Races & 4,874 & $\begin{array}{l}-0.298 \\
(0.241)\end{array}$ & $\begin{array}{l}-0.058 \\
(0.132)\end{array}$ & $\begin{array}{l}-0.386^{*} \\
(0.201)\end{array}$ & $\begin{array}{l}-0.018 \\
(0.164)\end{array}$ & $\begin{array}{l}-0.111^{*} \\
(0.066)\end{array}$ \\
\hline White & 15,425 & $\begin{array}{c}0.009 \\
(0.114)\end{array}$ & $\begin{array}{l}-0.047 \\
(0.058)\end{array}$ & $\begin{array}{l}-0.003 \\
(0.119)\end{array}$ & $\begin{array}{l}-0.054 \\
(0.089)\end{array}$ & $\begin{array}{l}-0.057 \\
(0.044)\end{array}$ \\
\hline Hispanic & 2,781 & $\begin{array}{l}-0.036 \\
(0.281)\end{array}$ & $\begin{array}{l}-0.135 \\
(0.126)\end{array}$ & $\begin{array}{l}-0.218 \\
(0.154)\end{array}$ & $\begin{array}{c}0.200 \\
(0.193)\end{array}$ & $\begin{array}{l}-0.066 \\
(0.052)\end{array}$ \\
\hline \multicolumn{7}{|c|}{ Panel 3: $<\$ 75,000$ in Financial Assets and $<$ College Degree } \\
\hline $\begin{array}{l}\geq \$ 75,000 \text { and } \\
\geq \text { College Degree }\end{array}$ & 5,292 & $\begin{array}{l}-0.218 \\
(0.182)\end{array}$ & $\begin{array}{l}-0.012 \\
(0.071)\end{array}$ & $\begin{array}{c}0.015 \\
(0.122)\end{array}$ & $\begin{array}{l}-0.025 \\
(0.247)\end{array}$ & $\begin{array}{c}0.014 \\
(0.070)\end{array}$ \\
\hline $\begin{array}{l}<\$ 75,000 \text { and } \\
<\text { College Degree, all }\end{array}$ & 12,654 & $\begin{array}{c}0.022 \\
(0.223)\end{array}$ & $\begin{array}{c}0.008 \\
(0.081)\end{array}$ & $\begin{array}{l}-0.124 \\
(0.144)\end{array}$ & $\begin{array}{l}-0.129 \\
(0.091)\end{array}$ & $\begin{array}{c}-0.130^{* *} \\
(0.055)\end{array}$ \\
\hline Black / Other Races & 4,100 & $\begin{array}{c}-0.682 * * * \\
(0.256)\end{array}$ & $\begin{array}{l}-0.133 \\
(0.151)\end{array}$ & $\begin{array}{c}-0.523^{* *} \\
(0.228)\end{array}$ & $\begin{array}{l}-0.080 \\
(0.177)\end{array}$ & $\begin{array}{l}-0.123 \\
(0.085)\end{array}$ \\
\hline White & 8,554 & $\begin{array}{c}0.233 \\
(0.273)\end{array}$ & $\begin{array}{c}0.060 \\
(0.088)\end{array}$ & $\begin{array}{l}-0.004 \\
(0.197)\end{array}$ & $\begin{array}{l}-0.193 * \\
(0.104)\end{array}$ & $\begin{array}{c}-0.150^{* *} \\
(0.070)\end{array}$ \\
\hline Hispanic & 2,342 & $\begin{array}{l}-0.104 \\
(0.341)\end{array}$ & $\begin{array}{l}-0.114 \\
(0.144)\end{array}$ & $\begin{array}{l}-0.283 \\
(0.200)\end{array}$ & $\begin{array}{c}0.079 \\
(0.164)\end{array}$ & $\begin{array}{l}-0.091 \\
(0.065)\end{array}$ \\
\hline
\end{tabular}




\begin{tabular}{lccccc}
\hline Non homeowners & & & & & \\
House Price Index & 0.328 & 0.128 & 0.508 & 0.306 & 0.045 \\
& $(0.507)$ & $(0.194)$ & $(0.313)$ & $(0.197)$ & $(0.240)$ \\
Not in labor force & -0.021 & $0.235^{* *}$ & 0.387 & -0.036 & 0.135 \\
& $(0.322)$ & $(0.117)$ & $(0.248)$ & $(0.160)$ & $(0.150)$ \\
Widowed & $0.899^{*}$ & 0.043 & 0.059 & -0.285 & 0.142 \\
& $(0.541)$ & $(0.155)$ & $(0.234)$ & $(0.351)$ & $(0.362)$ \\
Cancer & -0.236 & -0.100 & -0.418 & -0.223 & -0.072 \\
Observations & $(0.724)$ & $(0.454)$ & $(0.836)$ & $(0.153)$ & $(0.123)$ \\
Number of clusters & 1480 & 1550 & 1555 & 330 & 322 \\
$\mathrm{R}^{2}$ & 134 & 136 & 136 & 76 & 74 \\
& 0.74 & 0.70 & 0.83 & 0.80 & 0.80 \\
\hline
\end{tabular}

Note: All regressions include individual and year fixed effects and are weighted to represent our target population: a nationally representative sample of 51- to 61-year-old adults. Standard errors are clustered by core-based statistical area. ${ }^{*} \mathrm{p}<0.10,{ }^{* *} \mathrm{p}<0.05,{ }^{* * *} \mathrm{p}<0.01$. 


\section{Appendices}

Appendix Table A.1 Baseline Sample Characteristics by House Price Decline

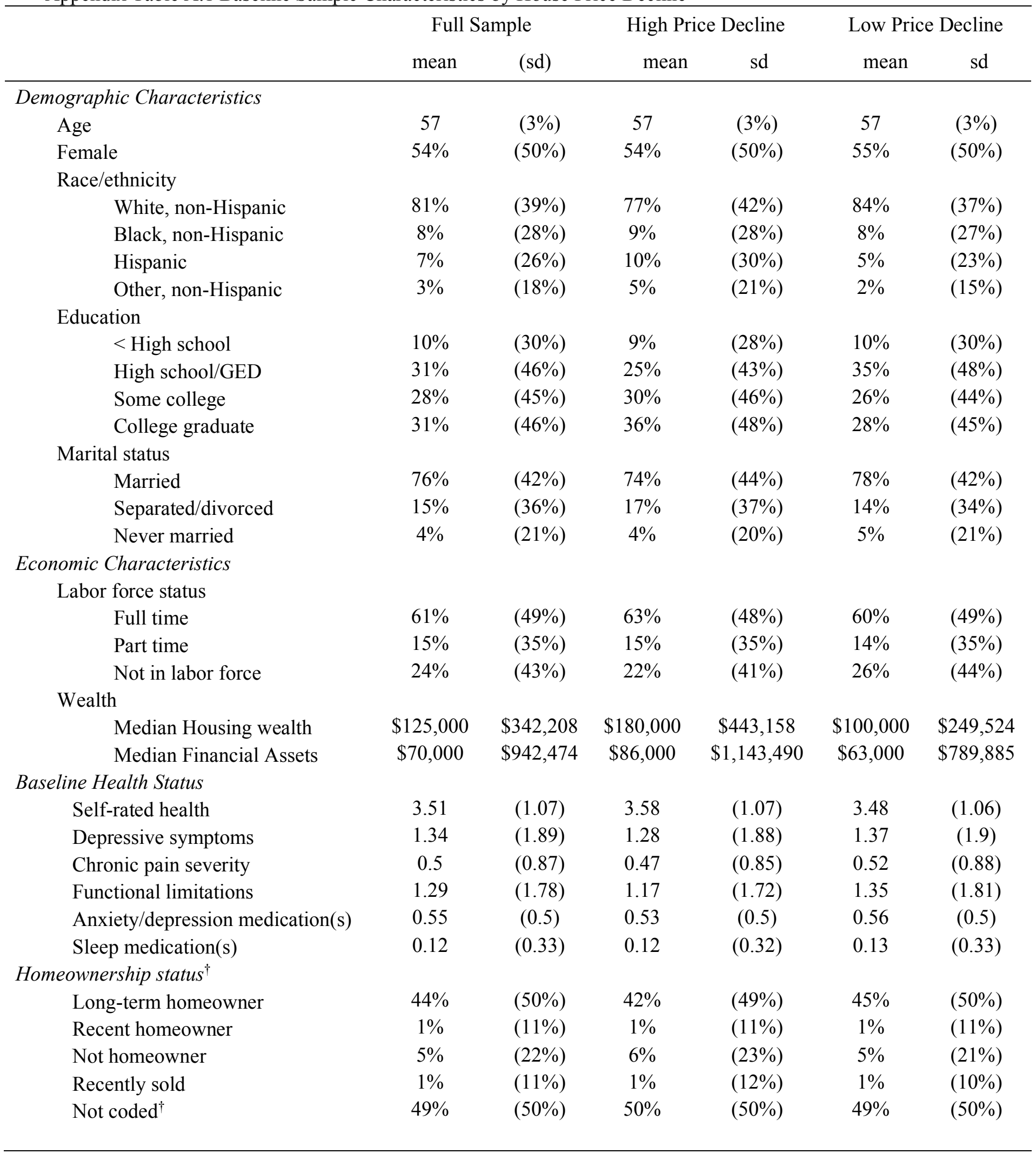




\begin{tabular}{|c|c|c|c|c|c|c|}
\hline \multicolumn{7}{|c|}{ Geographic Distribution } \\
\hline Rural & $4 \%$ & $(20 \%)$ & $0 \%$ & $(2 \%)$ & $4 \%$ & $(20 \%)$ \\
\hline Suburban & $15 \%$ & $(36 \%)$ & $3 \%$ & $(17 \%)$ & $25 \%$ & $(43 \%)$ \\
\hline Urban & $80 \%$ & $(40 \%)$ & $97 \%$ & $(17 \%)$ & $71 \%$ & $(45 \%)$ \\
\hline Observations & \multicolumn{2}{|c|}{27,887} & \multicolumn{2}{|c|}{11,279} & \multicolumn{2}{|c|}{15,941} \\
\hline Number of people & \multicolumn{2}{|c|}{9425} & \multicolumn{2}{|c|}{3793} & \multicolumn{2}{|c|}{5405} \\
\hline
\end{tabular}

All values are calculated for the study baseline between 2000 and 2004 and are weighted to represent a nationally representative sample of 51 to 61 year-old adults. Standard errors are clustered by core-based statistical area. ${ }^{\dagger}$ Tenure is based on the two most recent consecutive waves we observe between 2000 and 2004. Long-term homeowners are those who owned a home in both of those waves (e.g., 2002 and 2004 or 2000 and 2002); recent homeowners are those that bought a home within two to four years of the decline (i.e. between 2002 and 2004); recent sellers are those who sold a home within two to four years of the decline (also between 2002 and 2004). 
Appendix Table A.2 Health Measures from the Health and Retirement Study

Depressive Symptoms captured with the Center for Epidemiological Scale of Depression (CES-D): scale $(0-8)$

\begin{tabular}{|c|c|}
\hline CES-D indicator type & "Much of the time during the past week, you..." (yes/no) \\
\hline $\begin{array}{l}\text { Negative affect or somaticism } \\
\text { (1: yes, } 0: \text { no) }\end{array}$ & $\begin{array}{ll}\text { 1. } & \text { Felt depressed } \\
\text { 2. } & \text { Felt lonely } \\
\text { 3. } & \text { Felt sad } \\
\text { 4. } & \text { Could not get going } \\
\text { 5. } & \text { Felt that everything was an effort } \\
\text { 6. } & \text { Your sleep was restless }\end{array}$ \\
\hline $\begin{array}{l}\text { Diminished positive affect } \\
(1: \text { no, } 0: \text { yes })\end{array}$ & $\begin{array}{l}\text { 7. Felt happy } \\
\text { 8. Had a lot of energy }\end{array}$ \\
\hline
\end{tabular}

Chronic Pain: 0 (no pain) to 3 (severe pain)

\begin{tabular}{|l|l|}
\hline Corresponding score & HRS question(s) \\
\hline 0: no & Are you often troubled with pain? \\
\hline $\begin{array}{l}\text { 1: mild } \\
\text { 2: moderate } \\
\text { 3: severe }\end{array}$ & $\begin{array}{l}\text { If yes, how bad is the pain most of the time: mild, moderate, } \\
\text { or severe? }\end{array}$ \\
\hline
\end{tabular}

Functional Limitations: 0 (no limitations) to 7 (all limitations)

HRS question(s)

(1: yes, $0:$ no, total score $=$ sum of answers to seven questions)

Because of a health problem do you have any difficulty with...

1. Walking one block

2. Sitting for about two hours

3. Climbing one flight of stairs without resting

4. Stooping, kneeling, or crouching

5. Lifting or carrying weights over 10 pounds, like a heavy bag of groceries

6. Reaching or extending arms above shoulder level

7. Pulling or pushing large objects like a living room chair

Anxiety/Depression Medication Use: 0 (no) - 1 (yes)

HRS question(s)

Do you now take tranquilizers, antidepressants, or pills for nerves?

(1: yes, 0: no) 
Sleep Medication Use: 0 (no) - 1 (yes)

HRS question(s)

Do you regularly take prescription medications to help you sleep?

(1: yes, 0: no) 
Appendix Table A.3. Effect of House Prices on Older Adult Mental Health, Full Results

\begin{tabular}{|c|c|c|c|c|c|}
\hline & Depression & Chronic Pain & $\begin{array}{c}\text { (3) } \\
\text { Functional } \\
\text { Limitations }\end{array}$ & $\begin{array}{c}(4) \\
\text { Anxiety/ } \\
\text { Depression } \\
\text { Medications }\end{array}$ & $\begin{array}{c}(5) \\
\text { Sleep } \\
\text { Medications }\end{array}$ \\
\hline House Price Index & $\begin{array}{c}-0.067 \\
(0.083)\end{array}$ & $\begin{array}{c}-0.031 \\
(0.050)\end{array}$ & $\begin{array}{l}-0.045 \\
(0.085)\end{array}$ & $\begin{array}{l}-0.035 \\
(0.057)\end{array}$ & $\begin{array}{c}-0.038 \\
(0.030)\end{array}$ \\
\hline \multicolumn{6}{|c|}{ Demographic Characteristics ${ }^{\dagger}$} \\
\hline Part-time & $\begin{array}{c}0.061 \\
(0.052)\end{array}$ & $\begin{array}{c}0.038 \\
(0.024)\end{array}$ & $\begin{array}{c}0.100^{* *} \\
(0.041)\end{array}$ & $\begin{array}{c}0.030 \\
(0.043)\end{array}$ & $\begin{array}{c}0.020 \\
(0.021)\end{array}$ \\
\hline Not in labor force & $\begin{array}{c}0.259 * * * \\
(0.062)\end{array}$ & $\begin{array}{c}0.027 \\
(0.027)\end{array}$ & $\begin{array}{c}0.285^{* * *} \\
(0.045)\end{array}$ & $\begin{array}{c}0.021 \\
(0.042)\end{array}$ & $\begin{array}{c}-0.001 \\
(0.018)\end{array}$ \\
\hline \multicolumn{6}{|l|}{ Marital Status } \\
\hline Separated / Divorced & $\begin{array}{c}0.488 * * * \\
(0.124)\end{array}$ & $\begin{array}{c}-0.011 \\
(0.040)\end{array}$ & $\begin{array}{c}-0.053 \\
(0.070)\end{array}$ & $\begin{array}{c}0.018 \\
(0.050)\end{array}$ & $\begin{array}{c}0.057 \\
(0.037)\end{array}$ \\
\hline Widowed & $\begin{array}{c}0.796 * * * \\
(0.176)\end{array}$ & $\begin{array}{c}0.055 \\
(0.069)\end{array}$ & $\begin{array}{c}0.014 \\
(0.096)\end{array}$ & $\begin{array}{l}-0.030 \\
(0.103)\end{array}$ & $\begin{array}{c}0.024 \\
(0.053)\end{array}$ \\
\hline Never Married & $\begin{array}{c}0.276 \\
(0.315)\end{array}$ & $\begin{array}{c}0.106 \\
(0.115)\end{array}$ & $\begin{array}{c}0.167 \\
(0.176)\end{array}$ & $\begin{array}{c}0.118 \\
(0.196)\end{array}$ & $\begin{array}{l}-0.009 \\
(0.066)\end{array}$ \\
\hline Missing & $\begin{array}{c}1.132 \\
(0.847)\end{array}$ & $\begin{array}{c}0.063 \\
(0.178)\end{array}$ & $\begin{array}{c}0.234 \\
(0.217)\end{array}$ & $\begin{array}{c}0.053 \\
(0.053)\end{array}$ & $\begin{array}{c}0.146 \\
(0.124)\end{array}$ \\
\hline \multicolumn{6}{|l|}{ Age } \\
\hline $55-61$ & $\begin{array}{l}-0.025 \\
(0.061)\end{array}$ & $\begin{array}{c}0.034 \\
(0.028)\end{array}$ & $\begin{array}{c}0.004 \\
(0.041)\end{array}$ & $\begin{array}{l}-0.033 \\
(0.049)\end{array}$ & $\begin{array}{c}-0.024 \\
(0.025)\end{array}$ \\
\hline Female x $55-61$ & $\begin{array}{c}-0.044 \\
(0.064)\end{array}$ & $\begin{array}{c}-0.014 \\
(0.029)\end{array}$ & $\begin{array}{l}-0.051 \\
(0.047)\end{array}$ & $\begin{array}{c}0.028 \\
(0.052)\end{array}$ & $\begin{array}{c}0.018 \\
(0.026)\end{array}$ \\
\hline \multicolumn{6}{|l|}{ Financial Assets } \\
\hline $1^{\text {st }}$ quartile & $\begin{array}{c}0.208 * * * \\
(0.073)\end{array}$ & $\begin{array}{c}0.032 \\
(0.029)\end{array}$ & $\begin{array}{l}0.101 * \\
(0.054)\end{array}$ & $\begin{array}{c}0.046 \\
(0.047)\end{array}$ & $\begin{array}{c}0.018 \\
(0.022)\end{array}$ \\
\hline $2^{\text {nd }}$ quartile & $\begin{array}{l}-0.007 \\
(0.055)\end{array}$ & $\begin{array}{c}-0.004 \\
(0.022)\end{array}$ & $\begin{array}{c}0.037 \\
(0.040)\end{array}$ & $\begin{array}{c}0.005 \\
(0.036)\end{array}$ & $\begin{array}{l}-0.005 \\
(0.016)\end{array}$ \\
\hline $4^{\text {th }}$ quartile & $\begin{array}{c}0.031 \\
(0.047)\end{array}$ & $\begin{array}{c}0.002 \\
(0.023)\end{array}$ & $\begin{array}{l}-0.027 \\
(0.041)\end{array}$ & $\begin{array}{c}0.020 \\
(0.037)\end{array}$ & $\begin{array}{c}0.006 \\
(0.015)\end{array}$ \\
\hline $5^{\text {th }}$ quartile & $\begin{array}{c}0.022 \\
(0.068)\end{array}$ & $\begin{array}{c}-0.008 \\
(0.027)\end{array}$ & $\begin{array}{l}-0.052 \\
(0.049)\end{array}$ & $\begin{array}{c}0.035 \\
(0.050)\end{array}$ & $\begin{array}{c}0.004 \\
(0.018)\end{array}$ \\
\hline \multicolumn{6}{|l|}{ Health } \\
\hline Heart Disease & $\begin{array}{c}0.259 * * \\
(0.124)\end{array}$ & $\begin{array}{c}0.100 * * \\
(0.050)\end{array}$ & $\begin{array}{c}0.307 * * * \\
(0.112)\end{array}$ & $\begin{array}{l}-0.029 \\
(0.100)\end{array}$ & $\begin{array}{c}0.007 \\
(0.036)\end{array}$ \\
\hline High Blood Pressure & $\begin{array}{c}0.086 \\
(0.060)\end{array}$ & $\begin{array}{c}0.014 \\
(0.034)\end{array}$ & $\begin{array}{c}0.026 \\
(0.052)\end{array}$ & $\begin{array}{c}0.038 \\
(0.043)\end{array}$ & $\begin{array}{c}0.019 \\
(0.029)\end{array}$ \\
\hline Diabetes & $\begin{array}{c}0.061 \\
(0.110)\end{array}$ & $\begin{array}{c}0.008 \\
(0.045)\end{array}$ & $\begin{array}{c}0.145^{*} \\
(0.084)\end{array}$ & $\begin{array}{c}0.087 \\
(0.070)\end{array}$ & $\begin{array}{c}0.024 \\
(0.030)\end{array}$ \\
\hline Stroke & $\begin{array}{c}0.050 \\
(0.326)\end{array}$ & $\begin{array}{c}0.045 \\
(0.105)\end{array}$ & $\begin{array}{c}0.797 * * * \\
(0.286)\end{array}$ & $\begin{array}{l}0.146 * \\
(0.087)\end{array}$ & $\begin{array}{c}0.099 \\
(0.116)\end{array}$ \\
\hline Lung Disease & $\begin{array}{c}0.320 \\
(0.207)\end{array}$ & $\begin{array}{c}0.223 * * * \\
(0.084)\end{array}$ & $\begin{array}{c}0.452 * * * \\
(0.145)\end{array}$ & $\begin{array}{c}0.105 \\
(0.082)\end{array}$ & $\begin{array}{l}-0.017 \\
(0.058)\end{array}$ \\
\hline
\end{tabular}




\begin{tabular}{|c|c|c|c|c|c|}
\hline Arthritis & $\begin{array}{l}0.145^{*} \\
(0.074)\end{array}$ & $\begin{array}{c}0.169 * * * \\
(0.035)\end{array}$ & $\begin{array}{c}0.626 * * * \\
(0.079)\end{array}$ & $\begin{array}{c}0.072 \\
(0.048)\end{array}$ & $\begin{array}{l}0.036^{*} \\
(0.021)\end{array}$ \\
\hline Cancer & $\begin{array}{c}0.202 \\
(0.153)\end{array}$ & $\begin{array}{l}0.133 * \\
(0.070)\end{array}$ & $\begin{array}{c}0.322 * * * \\
(0.122)\end{array}$ & $\begin{array}{c}0.044 \\
(0.085)\end{array}$ & $\begin{array}{l}-0.006 \\
(0.035)\end{array}$ \\
\hline \multicolumn{6}{|l|}{ Year ${ }^{\S}$} \\
\hline 2002 & $\begin{array}{l}-0.065 \\
(0.052)\end{array}$ & $\begin{array}{c}0.024 \\
(0.025)\end{array}$ & $\begin{array}{c}0.071 \\
(0.046)\end{array}$ & $\begin{array}{c}0.024 \\
(0.038)\end{array}$ & \\
\hline 2004 & $\begin{array}{c}-0.159 * * \\
(0.067)\end{array}$ & $\begin{array}{c}0.085 * * * \\
(0.031)\end{array}$ & $\begin{array}{c}0.160 * * * \\
(0.051)\end{array}$ & $\begin{array}{l}-0.001 \\
(0.047)\end{array}$ & \\
\hline 2006 & $\begin{array}{l}-0.089 \\
(0.091)\end{array}$ & $\begin{array}{c}0.134 * * * \\
(0.041)\end{array}$ & $\begin{array}{c}0.293 * * * \\
(0.080)\end{array}$ & $\begin{array}{l}-0.027 \\
(0.065)\end{array}$ & $\begin{array}{l}-0.007 \\
(0.035)\end{array}$ \\
\hline 2008 & $\begin{array}{c}-0.234 * * \\
(0.099)\end{array}$ & $\begin{array}{c}0.117 * * * \\
(0.043)\end{array}$ & $\begin{array}{c}0.239 * * * \\
(0.078)\end{array}$ & $\begin{array}{l}-0.071 \\
(0.071)\end{array}$ & $\begin{array}{c}0.015 \\
(0.034)\end{array}$ \\
\hline 2010 & $\begin{array}{c}-0.331 * * * \\
(0.101)\end{array}$ & $\begin{array}{c}0.139 * * * \\
(0.045)\end{array}$ & $\begin{array}{c}0.284 * * * \\
(0.085)\end{array}$ & $\begin{array}{l}-0.081 \\
(0.074)\end{array}$ & $\begin{array}{l}-0.001 \\
(0.032)\end{array}$ \\
\hline 2012 & $\begin{array}{c}-0.381 * * * \\
(0.117)\end{array}$ & $\begin{array}{c}0.115 * * \\
(0.047)\end{array}$ & $\begin{array}{c}0.244 * * * \\
(0.087)\end{array}$ & $\begin{array}{l}-0.138 * \\
(0.080)\end{array}$ & $\begin{array}{c}0.015 \\
(0.029)\end{array}$ \\
\hline 2014 & $\begin{array}{c}-0.461 * * * \\
(0.142)\end{array}$ & $\begin{array}{c}0.205 * * * \\
(0.059)\end{array}$ & $\begin{array}{c}0.253 * * \\
(0.106)\end{array}$ & & $\begin{array}{c}0.021 \\
(0.026)\end{array}$ \\
\hline 2016 & $\begin{array}{c}-0.489 * * * \\
(0.151)\end{array}$ & $\begin{array}{c}0.217 * * * \\
(0.080)\end{array}$ & $\begin{array}{l}0.370 * * \\
(0.149)\end{array}$ & & \\
\hline Observations & 26,321 & 27,835 & 27,887 & 4,542 & 9,701 \\
\hline Number of clusters & 356 & 359 & 359 & 218 & 244 \\
\hline $\mathrm{R}^{2}$ & 0.69 & 0.68 & 0.78 & 0.75 & 0.77 \\
\hline
\end{tabular}

Note: All regressions include individual and year fixed effects and are weighted to represent our target population: a nationally representative sample of 51- to 61-year-old adults. Standard errors are clustered by core-based statistical area. * $\mathrm{p}<0.10,{ }^{* *} \mathrm{p}<0.05,{ }^{* * *} \mathrm{p}<0.01 .{ }^{\dagger}$ Reference categories: full-time, married, $51-54 .{ }^{\star}$ Quantiles of financial assets are $1^{\text {st }}:<$ $\$ 2.3 \mathrm{~K}, 2^{\text {nd }}: \$ 2.3 \mathrm{~K}-\$ 25 \mathrm{~K}, 3^{\text {rd: }}:>\$ 25 \mathrm{~K}-\$ 105.6 \mathrm{~K} 4^{\text {th }}: \$ 105.6 \mathrm{~K}-\$ 363 \mathrm{~K}, 5^{\text {th }}:>\$ 363 \mathrm{~K}$; reference category: $3^{\text {rd }}$ quantile.

\$Reference year: 2000 
Appendix Table A.4. Baseline Characteristics of Economically Vulnerable Households and Households of Differing Tenure

\begin{tabular}{|c|c|c|c|c|c|c|c|c|c|c|c|c|c|c|}
\hline & \multicolumn{2}{|c|}{$\begin{array}{l}\text { Black / Other non- } \\
\text { White Race }\end{array}$} & \multicolumn{2}{|c|}{$<$ College } & \multicolumn{2}{|c|}{$\begin{array}{c}<\$ 75,000 \text { in } \\
\text { Financial Assets }\end{array}$} & \multicolumn{2}{|c|}{ Recent Owners } & \multicolumn{2}{|c|}{ Longer Term Owners } & \multicolumn{2}{|c|}{ Recently Sold } & \multicolumn{2}{|c|}{ Non-Homeowners } \\
\hline & mean & sd & mean & $\mathrm{sd}$ & mean & $\mathrm{sd}$ & mean & sd & mean & sd & mean & sd & mean & sd \\
\hline \multicolumn{15}{|l|}{ Demographic } \\
\hline Age & 57 & 3 & 57 & 3 & 57 & 3 & 58 & 3 & 58 & 3 & 57 & 3 & 58 & 3 \\
\hline Female & 0.56 & 0.5 & 0.57 & 0.5 & 0.55 & 0.5 & 0.64 & 0.48 & 0.58 & 0.49 & 0.61 & 0.49 & 0.57 & 0.5 \\
\hline \multicolumn{15}{|l|}{ Race } \\
\hline White, non-Hispanic & - & - & 0.78 & 0.42 & 0.72 & 0.45 & 0.75 & 0.44 & 0.85 & 0.36 & 0.59 & 0.49 & 0.6 & 0.49 \\
\hline Black, non-Hispanic & 0.8 & 0.4 & 0.13 & 0.33 & 0.17 & 0.37 & 0.18 & 0.39 & 0.09 & 0.28 & 0.27 & 0.44 & 0.21 & 0.41 \\
\hline Hispanic & 0.2 & 0.4 & 0.09 & 0.29 & 0.11 & 0.31 & 0.07 & 0.26 & 0.06 & 0.24 & 0.14 & 0.35 & 0.19 & 0.39 \\
\hline \multicolumn{15}{|l|}{ Education } \\
\hline$<$ High school & 0.23 & 0.42 & 0.14 & 0.35 & 0.15 & 0.36 & 0.17 & 0.38 & 0.09 & 0.29 & 0.15 & 0.36 & 0.27 & 0.44 \\
\hline High school degree & 0.29 & 0.45 & 0.45 & 0.5 & 0.38 & 0.49 & 0.35 & 0.48 & 0.34 & 0.47 & 0.39 & 0.49 & 0.35 & 0.48 \\
\hline Some college & 0.27 & 0.44 & 0.41 & 0.49 & 0.28 & 0.45 & 0.31 & 0.46 & 0.27 & 0.44 & 0.26 & 0.44 & 0.2 & 0.4 \\
\hline College graduate & 0.22 & 0.41 & - & - & 0.19 & 0.39 & 0.17 & 0.37 & 0.3 & 0.46 & 0.2 & 0.4 & 0.18 & 0.39 \\
\hline \multicolumn{15}{|l|}{ Marital status } \\
\hline Married & 0.63 & 0.48 & 0.75 & 0.43 & 0.69 & 0.46 & 0.51 & 0.5 & 0.83 & 0.37 & 0.55 & 0.5 & 0.43 & 0.49 \\
\hline Separated/divorced & 0.22 & 0.41 & 0.16 & 0.37 & 0.2 & 0.4 & 0.35 & 0.48 & 0.1 & 0.3 & 0.29 & 0.46 & 0.38 & 0.48 \\
\hline Never married & 0.08 & 0.27 & 0.05 & 0.22 & 0.06 & 0.24 & 0.08 & 0.27 & 0.05 & 0.21 & 0.13 & 0.34 & 0.1 & 0.3 \\
\hline \multicolumn{15}{|l|}{ Labor force status } \\
\hline Full time & 0.59 & 0.49 & 0.58 & 0.49 & 0.63 & 0.48 & 0.5 & 0.5 & 0.6 & 0.49 & 0.54 & 0.5 & 0.56 & 0.5 \\
\hline Part time & 0.12 & 0.33 & 0.14 & 0.35 & 0.13 & 0.33 & 0.19 & 0.39 & 0.16 & 0.36 & 0.16 & 0.36 & 0.11 & 0.31 \\
\hline Not in labor force & 0.29 & 0.45 & 0.28 & 0.45 & 0.25 & 0.43 & 0.31 & 0.46 & 0.25 & 0.43 & 0.31 & 0.46 & 0.33 & 0.47 \\
\hline \multicolumn{15}{|l|}{ Wealth } \\
\hline Median housing wealth & $\$ 70,000$ & $\$ 577,412$ & $\$ 100,000$ & $\$ 365,486$ & $\$ 80,000$ & $\$ 115,303$ & - & $\$ 206,343$ & $\$ 144,000$ & $\$ 392,135$ & $\$ 25,000$ & $\$ 212,553$ & $\$-$ & $\$ 22,990$ \\
\hline Median financial assets & $\$ 12,500$ & $\$ 496,239$ & $\$ 42,500$ & $\$ 675,206$ & $\$ 17,000$ & $\$ 44,181$ & $\$ 23,000$ & $\$ 403,051$ & $\$ 102,000$ & $\$ 1,040,887$ & $\$ 17,330$ & $\$ 764,792$ & $\$ 6,000$ & $\$ 267,989$ \\
\hline \multicolumn{15}{|l|}{ Baseline Health } \\
\hline Self-rated health & 3.08 & 1.1 & 3.35 & 1.07 & 3.28 & 1.1 & 3.44 & 1.12 & 3.58 & 1.02 & 3.13 & 1.2 & 3.16 & 1.2 \\
\hline Depressive symptoms & 1.83 & 2.16 & 1.53 & 2.01 & 1.62 & 2.07 & 2 & 2.21 & 1.19 & 1.75 & 2.16 & 2.35 & 2.02 & 2.35 \\
\hline Chronic pain severity & 0.56 & 0.95 & 0.58 & 0.92 & 0.6 & 0.94 & 0.44 & 0.83 & 0.49 & 0.86 & 0.74 & 1.07 & 0.63 & 0.99 \\
\hline Functional limitations & 1.61 & 2.12 & 1.5 & 1.89 & 1.55 & 1.96 & 1.54 & 1.95 & 1.27 & 1.71 & 1.95 & 2.37 & 1.83 & 2.21 \\
\hline Anxiety/depression med(s) & 0.49 & 0.5 & 0.55 & 0.5 & 0.54 & 0.5 & 0.5 & 0.5 & 0.57 & 0.5 & 0.38 & 0.49 & 0.42 & 0.5 \\
\hline Sleep medication(s) & 0.09 & 0.29 & 0.12 & 0.33 & 0.12 & 0.32 & supp. & supp. & 0.13 & 0.33 & supp. & supp. & 0.1 & 0.3 \\
\hline
\end{tabular}


Homeownership status ${ }^{\dagger}$

\begin{tabular}{|c|c|c|c|c|c|c|c|c|c|c|c|c|c|c|}
\hline Long term homeowner & 0.31 & 0.46 & 0.45 & 0.5 & 0.39 & 0.49 & - & - & 1 & - & - & - & - & - \\
\hline Recent homeowner & 0.02 & 0.13 & 0.01 & 0.12 & 0.01 & 0.12 & 1 & - & - & - & - & - & - & - \\
\hline Not homeowner & 0.1 & 0.3 & 0.06 & 0.24 & 0.08 & 0.27 & - & - & - & - & - & - & 1 & - \\
\hline Seller & 0.03 & 0.17 & 0.01 & 0.12 & 0.02 & 0.13 & - & - & - & - & 1 & - & - & - \\
\hline Not coded & 0.55 & 0.5 & 0.47 & 0.5 & 0.5 & 0.5 & - & - & - & - & - & - & - & - \\
\hline graphic Distribution $\dagger$ & & & & & & & & & & & & & & \\
\hline Rural & 0.03 & 0.16 & 0.04 & 0.21 & 0.04 & 0.2 & 0.06 & 0.23 & 0.04 & 0.21 & 0.04 & 0.19 & 0.03 & 0.17 \\
\hline Suburban & 0.11 & 0.32 & 0.17 & 0.38 & 0.16 & 0.37 & 0.11 & 0.32 & 0.16 & 0.37 & 0.15 & 0.36 & 0.1 & 0.31 \\
\hline Urban & 0.86 & 0.35 & 0.78 & 0.41 & 0.79 & 0.4 & 0.83 & 0.37 & 0.79 & 0.41 & 0.82 & 0.39 & 0.87 & 0.34 \\
\hline gh house price decline & 0.49 & 0.5 & 0.38 & 0.49 & 0.38 & 0.49 & 0.41 & 0.49 & 0.39 & 0.49 & 0.52 & 0.5 & 0.46 & 0.5 \\
\hline ervations & \multicolumn{2}{|c|}{6,070} & \multicolumn{2}{|c|}{20,299} & \multicolumn{2}{|c|}{14,950} & \multicolumn{2}{|c|}{383} & \multicolumn{2}{|c|}{13,062} & \multicolumn{2}{|c|}{380} & \multicolumn{2}{|c|}{1,555} \\
\hline ber of people & \multicolumn{2}{|c|}{2,046} & \multicolumn{2}{|c|}{7,061} & \multicolumn{2}{|c|}{6,072} & \multicolumn{2}{|c|}{154} & \multicolumn{2}{|c|}{4,939} & \multicolumn{2}{|c|}{147} & \multicolumn{2}{|c|}{614} \\
\hline
\end{tabular}

$\dagger$ Geographic categories are based on the 2013 rural-urban continuum codes from the USDA. Urban refers to codes 1, 2, and 3; suburban to codes 4, 5, and 6; and rural to 7, 8 and 9. Tenure is based on the two most recent consecutive waves we observe between 2000 and 2004. Long-term homeowners are those who owned a home in both of those waves (e.g., 2002 and 2004 or 2000 and 2002); recent homeowners are those that bought a home within two to four years of the decline (i.e. between 2002 and 2004); recent sellers are those who sold a home within two to four years of the decline (also between 2002 and 2004). 
Appendix Table A.5. Alternative Definitions for Race and Ethnicity in Table 2

\begin{tabular}{|c|c|c|c|c|c|}
\hline & (1) & (2) & (3) & (4) & (5) \\
\hline & $\begin{array}{c}\text { Main } \\
\text { specification }\end{array}$ & $\begin{array}{c}\text { Disaggregates } \\
\text { ethnicity }\end{array}$ & $\begin{array}{c}\text { Disaggregates } \\
\text { race }\end{array}$ & $\begin{array}{c}\text { Disaggregates } \\
\text { race and } \\
\text { ethnicity }\end{array}$ & $\begin{array}{c}\text { By ethnicity } \\
\text { only }\end{array}$ \\
\hline House Price Index & $\begin{array}{c}0.072 \\
(0.124)\end{array}$ & $\begin{array}{c}0.062 \\
(0.123)\end{array}$ & $\begin{array}{c}0.071 \\
(0.122)\end{array}$ & $\begin{array}{c}0.062 \\
(0.123)\end{array}$ & $\begin{array}{c}0.055 \\
(0.125)\end{array}$ \\
\hline x Black and Other Races & $\begin{array}{l}-0.239 \\
(0.165)\end{array}$ & $\begin{array}{l}-0.275 \\
(0.174)\end{array}$ & & & \\
\hline x Black only & & & $\begin{array}{l}-0.268 \\
(0.328)\end{array}$ & $\begin{array}{l}-0.248 \\
(0.329)\end{array}$ & \\
\hline $\mathrm{x}$ Other races only & & & $\begin{array}{l}-0.212 \\
(0.201)\end{array}$ & $\begin{array}{l}-0.304 \\
(0.216)\end{array}$ & \\
\hline x Hispanic ethnicity & & $\begin{array}{c}0.240 \\
(0.179)\end{array}$ & & $\begin{array}{c}0.251 \\
(0.176) \\
\end{array}$ & $\begin{array}{c}0.188 \\
(0.180) \\
\end{array}$ \\
\hline Observations & 26321 & 26321 & 26321 & 26321 & 26321 \\
\hline Number of clusters & 356 & 356 & 356 & 356 & 356 \\
\hline $\mathrm{R}^{2}$ & 0.69 & 0.69 & 0.69 & 0.69 & 0.69 \\
\hline
\end{tabular}

Standard errors are clustered by core-based statistical area. All regressions include individual and year fixed effects and are weighted to represent our target population: a nationally representative sample of 51- to 61-year-old adults. $* \mathrm{p}<0.10, * * \mathrm{p}<0.05, * * * \mathrm{p}<0.01$ 
Appendix Table A.6. Alternative Definitions for Race and Ethnicity in Table 3

(1) (2) (3) $\quad$ (4)

Black \& other Black w/Hispanic
(3) w/Hispanic
(4)

Black and w/Hispanic
(5)

(6)

\begin{tabular}{ccc}
$\begin{array}{c}\text { Other Races, } \\
\text { non-Hispanic }\end{array}$ & $\begin{array}{c}\text { Black, non- } \\
\text { Hispanic }\end{array}$ & $\begin{array}{c}\text { Other Races, } \\
\text { non-Hispanic }\end{array}$ \\
\hline
\end{tabular}

\begin{tabular}{lcccccc}
\hline House Price Index & $-0.731 * *$ & $-0.777 * *$ & -0.457 & $-1.058^{* * *}$ & -0.504 & $-1.441 * *$ \\
& $(0.283)$ & $(0.373)$ & $(0.506)$ & $(0.313)$ & $(0.510)$ & $(0.671)$ \\
\hline Observations & 3929 & 3059 & 2634 & 1295 & 2607 & 452 \\
Number of clusters & 134 & 120 & 94 & 93 & 93 & 73 \\
$\mathrm{R}^{2}$ & 0.72 & 0.72 & 0.72 & 0.73 & 0.72 & 0.76 \\
\hline
\end{tabular}

Standard errors are clustered by core-based statistical area. All regressions include individual and year fixed effects and are weighted to represent our target population: a nationally representative sample of 51- to 61-year-old adults. $\mathrm{p}<0.10, * * \mathrm{p}<0.05, * * * \mathrm{p}<0.01$ 
Appendix Figure B.1. House Price Changes between 2006 and 2012 by CBSA*

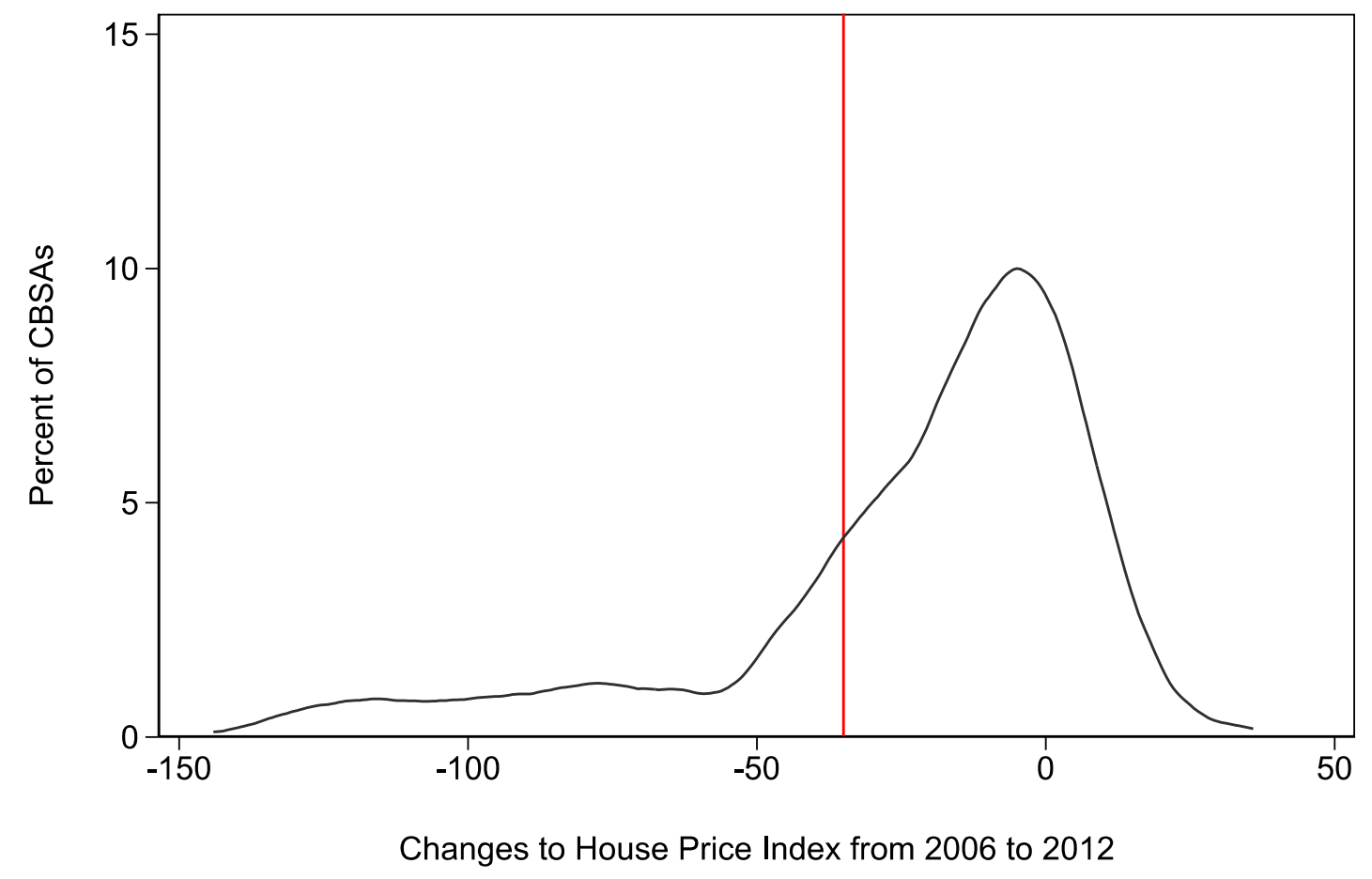

*Values correspond to changes in the House Price Index, which is normalized to 100 in 2000 
Appendix Figure B.2. Robustness of Table 3 Panel 2 Estimates, Homeowners by Level of Education
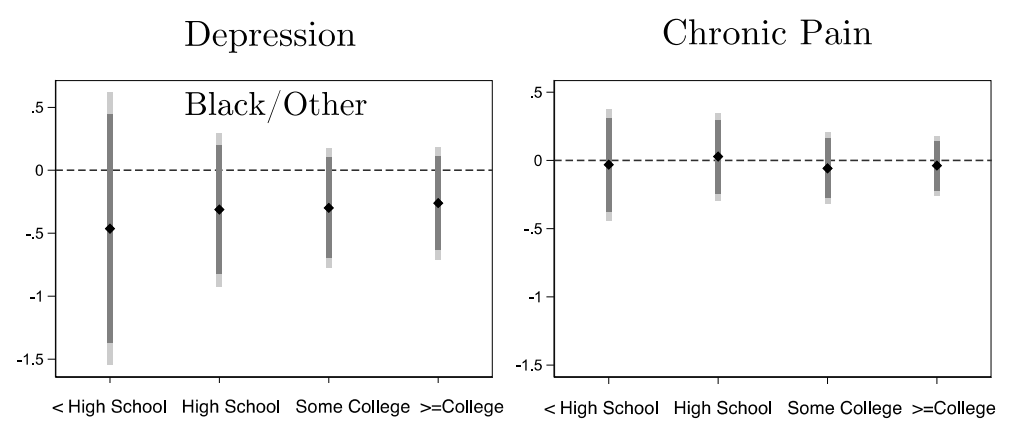

Functional Limitations

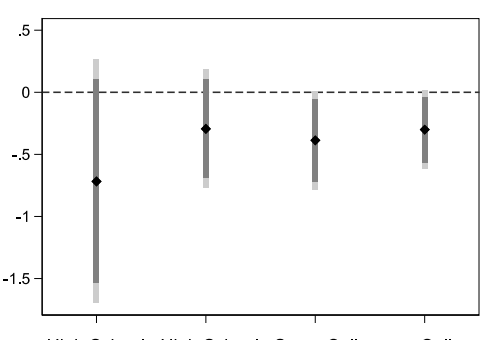

$<$ High School High School Some College >=Colleg

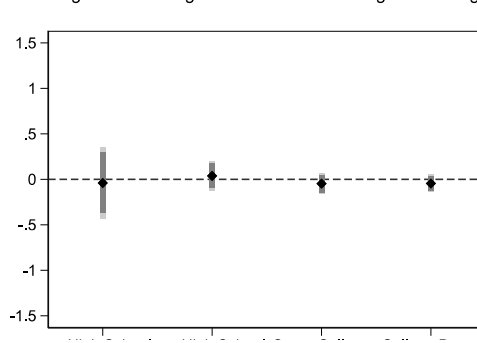

$<$ High School High School Some College >=College

$<$ High School High School Some College >=College

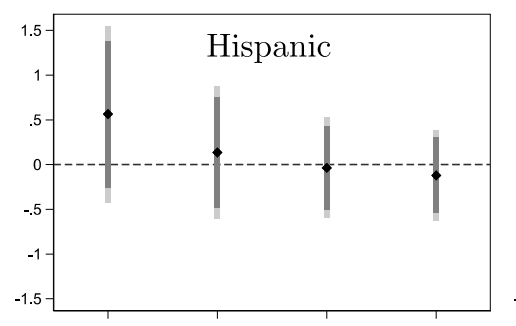

$<$ High School High School Some College >=College

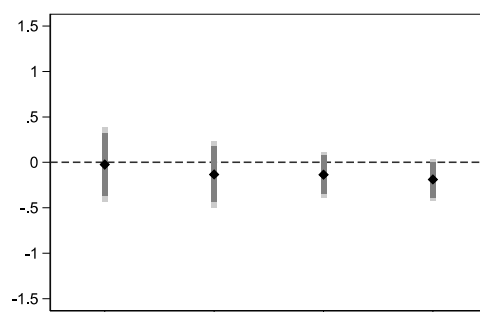

$<$ High School High School Some College >=College

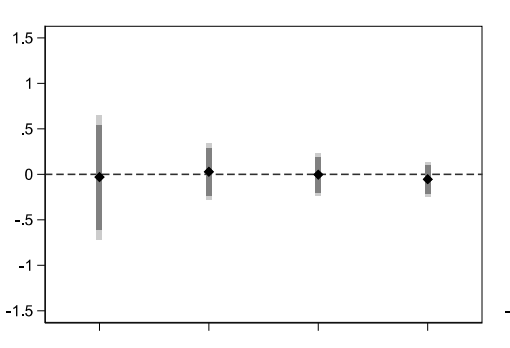

$<$ High School High School Some College >=College

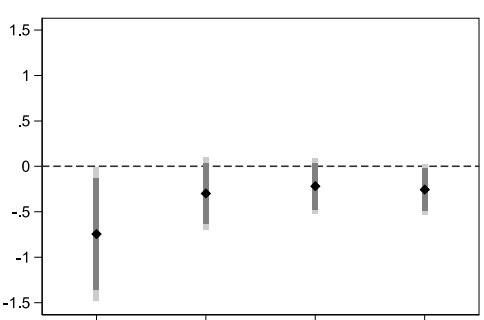

$<$ High School High School Some College >=College
Anxiety/Dep. Medication
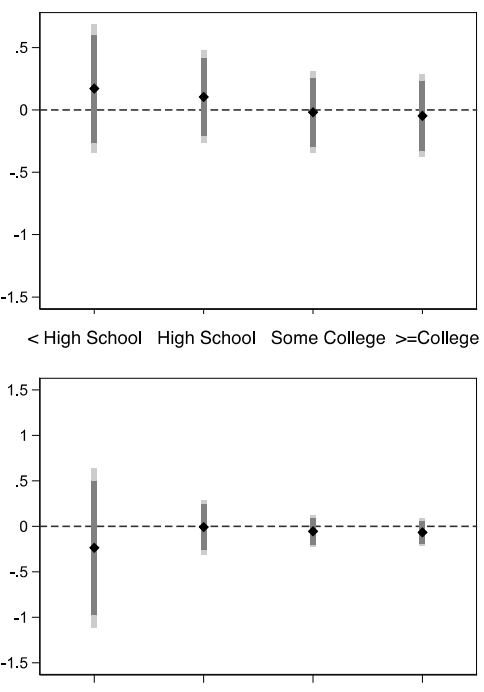

< High School High School Some College >=College

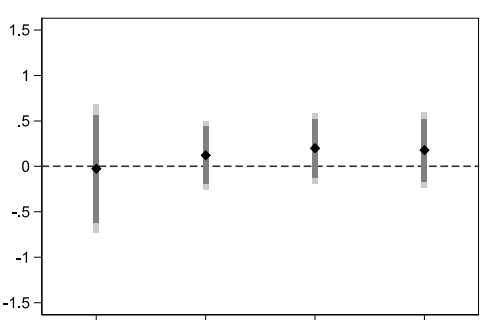

$<$ High School High School Some College >=College
Sleep Medication
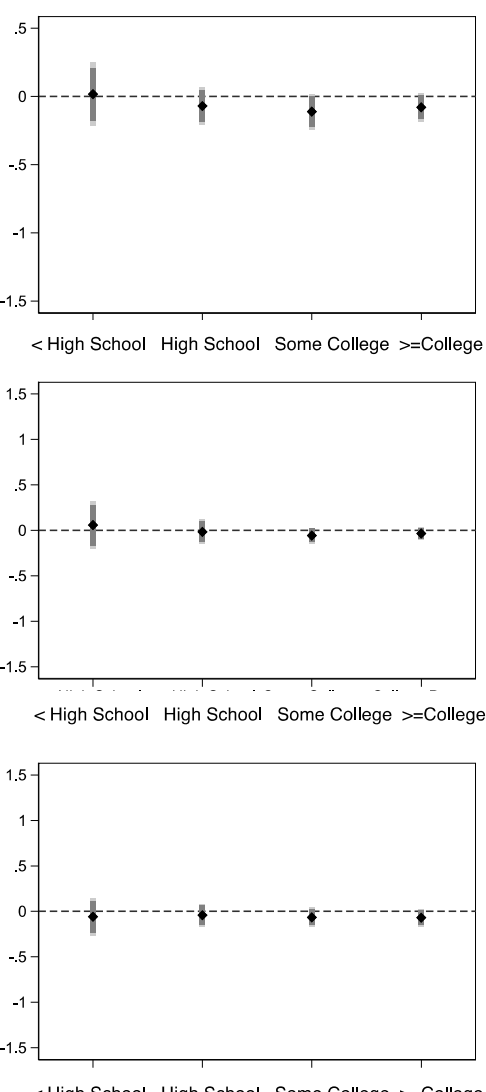

$<$ High School High School Some College >=College

Bars show the coefficient on the house price index from equation (1) run on the subgroup in each row; dots are point estimates and bars are confidence intervals (dark bar: 95\% CI, light bar: 99\% CI). Rows correspond to the last three rows of panel 2 in Table 3 where education is varied across four groups: less than a high school degree, a high school degree, some college, and a four year college degree or more. 
Appendix Figure B.3. Robustness of Table 3 Panel 3 Estimates, Homeowners with Less than a College Degree ${ }^{\dagger}$ and Few Financial Assets
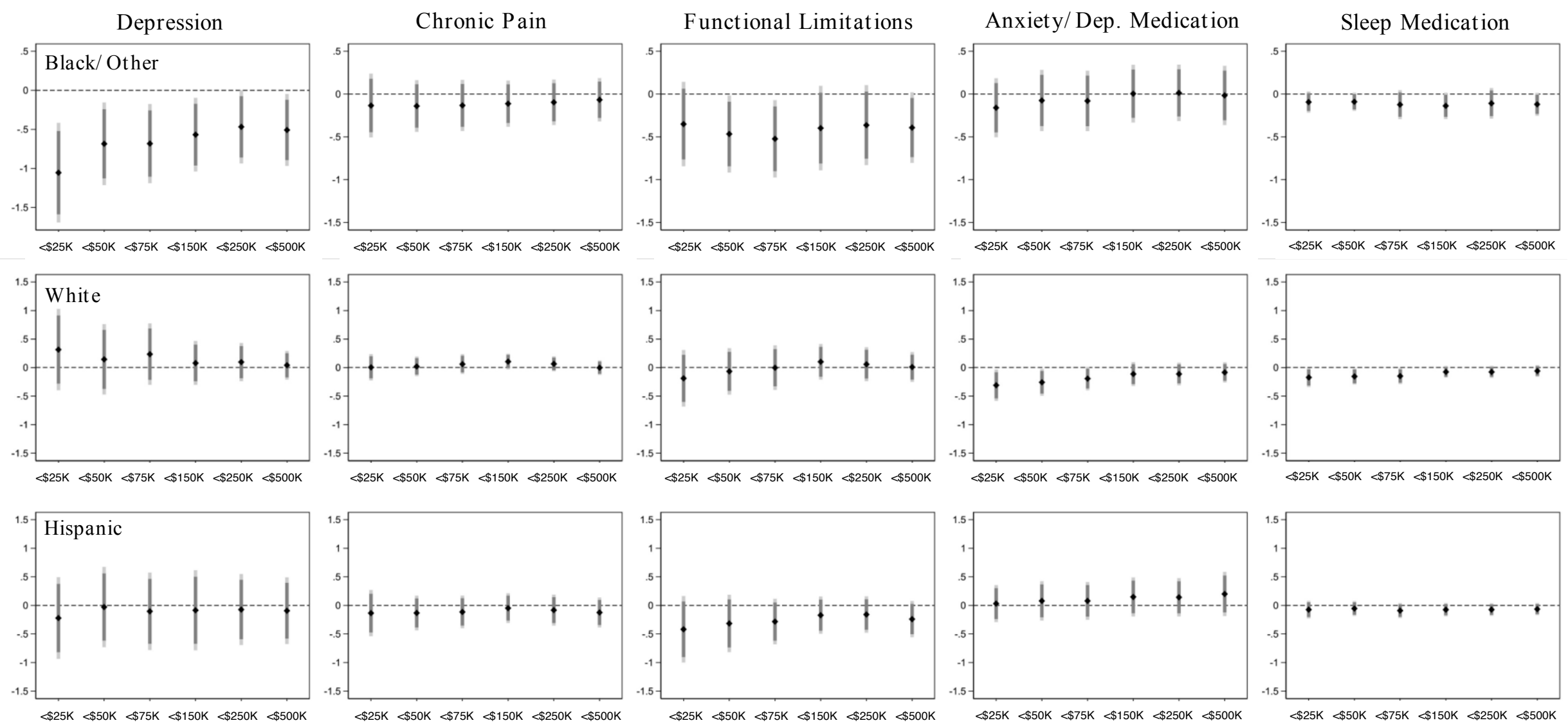

Bars show the coefficient on the house price index from equation (1) run on the subgroup in each row; dots are point estimates and bars are confidence intervals (dark bar: 95\% CI, light bar: 99\% CI). Rows correspond to the last three rows of panel 3 in Table 3 where the definition of financial assets are varied in 10 percentile increments from roughly the 30 th to the 80 th percentiles.

${ }^{\dagger}$ All samples are restricted to those with less than a four year college degree. 
Appendix Table B.4. Effect of the Unemployment Rate on Health

\begin{tabular}{|c|c|c|c|c|c|}
\hline & $\begin{array}{c}\text { (1) } \\
\text { Depression }\end{array}$ & $\begin{array}{l}\text { (2) } \\
\text { Chronic Pain }\end{array}$ & $\begin{array}{c}\text { (3) } \\
\text { Functional } \\
\text { Limitations }\end{array}$ & $\begin{array}{c}\text { (4) } \\
\text { Anxiety/ } \\
\text { Depression } \\
\text { Medications } \\
\end{array}$ & $\begin{array}{c}\text { (5) } \\
\text { Sleep } \\
\text { Medications }\end{array}$ \\
\hline \multicolumn{6}{|l|}{ Full Sample } \\
\hline Unemployment Rate & $\begin{array}{c}1.793 \\
(1.689)\end{array}$ & $\begin{array}{c}-0.324 \\
(0.894)\end{array}$ & $\begin{array}{l}-0.116 \\
(1.928)\end{array}$ & $\begin{array}{c}0.047 \\
(1.115)\end{array}$ & $\begin{array}{c}0.384 \\
(0.518)\end{array}$ \\
\hline Observations & 26321 & 27835 & 27887 & 4542 & 9701 \\
\hline Number of clusters & 356 & 359 & 359 & 218 & 244 \\
\hline \multicolumn{6}{|l|}{ Homeowners } \\
\hline Unemployment Rate & $\begin{array}{c}1.923 \\
(1.711)\end{array}$ & $\begin{array}{l}-0.264 \\
(0.896)\end{array}$ & $\begin{array}{c}0.214 \\
(1.944)\end{array}$ & $\begin{array}{l}-0.023 \\
(1.148)\end{array}$ & $\begin{array}{c}0.409 \\
(0.524)\end{array}$ \\
\hline Observations & 24841 & 26285 & 26332 & 4212 & 9379 \\
\hline Number of clusters & 334 & 337 & 337 & 208 & 232 \\
\hline \multicolumn{6}{|c|}{ Homeowners with one home } \\
\hline Unemployment Rate & $\begin{array}{c}1.841 \\
(2.041)\end{array}$ & $\begin{array}{l}-0.625 \\
(1.076)\end{array}$ & $\begin{array}{c}0.216 \\
(1.971)\end{array}$ & $\begin{array}{l}-0.376 \\
(1.353)\end{array}$ & $\begin{array}{c}0.310 \\
(0.588)\end{array}$ \\
\hline Observations & 21381 & 22659 & 22698 & 3651 & 7685 \\
\hline Number of clusters & 330 & 334 & 334 & 204 & 216 \\
\hline \multicolumn{6}{|l|}{ Non homeowners } \\
\hline Unemployment Rate & $\begin{array}{c}-3.330 \\
(11.057)\end{array}$ & $\begin{array}{l}-0.713 \\
(4.492)\end{array}$ & $\begin{array}{l}-6.867 \\
(7.577)\end{array}$ & $\begin{array}{c}0.628 \\
(5.458)\end{array}$ & $\begin{array}{l}-2.795 \\
(3.467)\end{array}$ \\
\hline Observations & 1480 & 1550 & 1555 & 330 & 322 \\
\hline Number of clusters & 134 & 136 & 136 & 76 & 74 \\
\hline
\end{tabular}

Standard errors are clustered by commuting zone All regressions include individual and year fixed effects and are weighted to represent a nationally representative sample of 65 - to 74 -year-old adults. $* \mathrm{p}<0.10$, $* * \mathrm{p}<0.05, * * * \mathrm{p}<0.01$ 
Appendix Table B.5. Additional Effect of Unemployment by Race, Education, Financial Assets, and Tenure

\begin{tabular}{|c|c|c|c|c|c|}
\hline & $\begin{array}{c}\text { (1) } \\
\text { Depression }\end{array}$ & $\begin{array}{c}\text { (2) } \\
\text { Chronic Pain }\end{array}$ & $\begin{array}{c}\text { (3) } \\
\text { Functional } \\
\text { Limitations }\end{array}$ & $\begin{array}{c}(4) \\
\text { Anxiety/ } \\
\text { Depression } \\
\text { Medications }\end{array}$ & $\begin{array}{c}\text { (5) } \\
\text { Sleep } \\
\text { Medications }\end{array}$ \\
\hline Unemployment Rate & $\begin{array}{l}-0.194 \\
(2.054)\end{array}$ & $\begin{array}{l}-1.025 \\
(1.133)\end{array}$ & $\begin{array}{l}-3.793 * \\
(2.028)\end{array}$ & $\begin{array}{c}1.255 \\
(2.275)\end{array}$ & $\begin{array}{c}0.438 \\
(0.784)\end{array}$ \\
\hline x Black Non-Hispanic & $\begin{array}{l}-2.325 \\
(2.445)\end{array}$ & $\begin{array}{l}1.652 * \\
(0.983)\end{array}$ & $\begin{array}{c}0.801 \\
(2.170)\end{array}$ & $\begin{array}{c}0.110 \\
(1.700)\end{array}$ & $\begin{array}{l}-0.618 \\
(0.426)\end{array}$ \\
\hline x Other Non-Hispanic & $\begin{array}{l}-2.145 \\
(3.371)\end{array}$ & $\begin{array}{l}-0.206 \\
(1.277)\end{array}$ & $\begin{array}{c}0.602 \\
(2.222)\end{array}$ & $\begin{array}{l}-0.121 \\
(1.510)\end{array}$ & $\begin{array}{c}0.199 \\
(0.677)\end{array}$ \\
\hline x Hispanic & $\begin{array}{l}-3.943 \\
(3.604)\end{array}$ & $\begin{array}{c}0.931 \\
(1.389)\end{array}$ & $\begin{array}{l}-0.939 \\
(2.619)\end{array}$ & $\begin{array}{c}0.024 \\
(1.517)\end{array}$ & $\begin{array}{l}-0.841 * \\
(0.508)\end{array}$ \\
\hline x College Degree & $\begin{array}{c}1.750 \\
(1.552)\end{array}$ & $\begin{array}{c}0.359 \\
(0.832)\end{array}$ & $\begin{array}{l}2.797 * \\
(1.422)\end{array}$ & $\begin{array}{l}-0.747 \\
(1.474)\end{array}$ & $\begin{array}{c}0.001 \\
(0.444)\end{array}$ \\
\hline $\mathrm{x}<75,000$ in financial assets & $\begin{array}{c}0.503 \\
(1.625)\end{array}$ & $\begin{array}{l}-0.133 \\
(0.704)\end{array}$ & $\begin{array}{c}1.339 \\
(1.119)\end{array}$ & $\begin{array}{l}-1.028 \\
(1.193)\end{array}$ & $\begin{array}{c}0.247 \\
(0.355)\end{array}$ \\
\hline x Recent homeowners & $\begin{array}{c}2.059 \\
(9.916)\end{array}$ & $\begin{array}{l}-2.999 \\
(4.659)\end{array}$ & $\begin{array}{c}6.338 \\
(5.579)\end{array}$ & $\begin{array}{c}0.960 \\
(6.157)\end{array}$ & $\begin{array}{c}0.020 \\
(1.069)\end{array}$ \\
\hline x Recently sold & $\begin{array}{c}7.671 \\
(9.760)\end{array}$ & $\begin{array}{c}1.382 \\
(3.855)\end{array}$ & $\begin{array}{c}2.868 \\
(5.268)\end{array}$ & $\begin{array}{l}-2.635 \\
(5.846)\end{array}$ & $\begin{array}{c}0.370 \\
(1.766)\end{array}$ \\
\hline x Not homeowner & $\begin{array}{l}-1.707 \\
(6.650)\end{array}$ & $\begin{array}{l}-0.714 \\
(2.157)\end{array}$ & $\begin{array}{l}-0.527 \\
(3.288)\end{array}$ & $\begin{array}{l}-0.441 \\
(3.309)\end{array}$ & $\begin{array}{l}-1.553 \\
(1.698)\end{array}$ \\
\hline Observations & 26321 & 27835 & 27887 & 4542 & 9701 \\
\hline Number of clusters & 356 & 359 & 359 & 218 & 244 \\
\hline $\mathrm{R}^{2}$ & 0.69 & 0.68 & 0.78 & 0.75 & 0.77 \\
\hline
\end{tabular}

Standard errors are clustered by commuting zone All regressions include individual and year fixed effects and are weighted to represent a nationally representative sample of 65 - to 74 -year-old adults. ${ }^{*} \mathrm{p}<0.10$, $* * \mathrm{p}<0.05, * * * \mathrm{p}<0.01$ 
Appendix Table B.6. Heterogeneous effects of the Unemployment Rate on Mental Health

\begin{tabular}{|c|c|c|c|c|c|c|}
\hline & & (1) & (2) & (3) & (4) & $(5)$ \\
\hline & Observations & Depression & $\begin{array}{c}\text { Pain } \\
\text { Severity }\end{array}$ & $\begin{array}{l}\text { Functional } \\
\text { Limitations }\end{array}$ & $\begin{array}{c}\text { Anxiety / } \\
\text { Depression } \\
\text { Medication }\end{array}$ & $\begin{array}{c}\text { Sleep } \\
\text { Medication }\end{array}$ \\
\hline \multicolumn{7}{|c|}{ Panel 1: $<\$ 75,000$ in Financial Assets } \\
\hline$\geq \$ 75,000$ & 12,937 & $\begin{array}{c}1.871 \\
(2.772)\end{array}$ & $\begin{array}{c}1.084 \\
(1.323)\end{array}$ & $\begin{array}{c}0.269 \\
(2.375)\end{array}$ & $\begin{array}{c}1.296 \\
(2.438)\end{array}$ & $\begin{array}{c}0.101 \\
(0.910)\end{array}$ \\
\hline$<\$ 75,000$, all & 14,950 & $\begin{array}{c}1.120 \\
(2.677)\end{array}$ & $\begin{array}{l}-1.258 \\
(1.362)\end{array}$ & $\begin{array}{c}1.315 \\
(3.203)\end{array}$ & $\begin{array}{l}-1.271 \\
(1.905)\end{array}$ & $\begin{array}{c}0.976 \\
(0.809)\end{array}$ \\
\hline Black / Other Races & 4,745 & $\begin{array}{c}4.754 \\
(5.085)\end{array}$ & $\begin{array}{c}1.339 \\
(2.116)\end{array}$ & $\begin{array}{c}5.436 \\
(4.221)\end{array}$ & $\begin{array}{c}0.628 \\
(4.101)\end{array}$ & $\begin{array}{c}0.688 \\
(1.534)\end{array}$ \\
\hline White & 10,205 & $\begin{array}{c}0.344 \\
(3.214)\end{array}$ & $\begin{array}{l}-1.806 \\
(1.572)\end{array}$ & $\begin{array}{c}0.443 \\
(3.757)\end{array}$ & $\begin{array}{l}-1.343 \\
(1.997)\end{array}$ & $\begin{array}{c}1.173 \\
(0.992)\end{array}$ \\
\hline Hispanic & 2,521 & $\begin{array}{l}-2.813 \\
(9.565)\end{array}$ & $\begin{array}{c}0.711 \\
(2.723)\end{array}$ & $\begin{array}{c}5.495 \\
(6.773)\end{array}$ & $\begin{array}{l}-1.593 \\
(3.503)\end{array}$ & $\begin{array}{c}0.791 \\
(1.473)\end{array}$ \\
\hline \multicolumn{7}{|l|}{ Panel 2: < College Degree } \\
\hline$\geq$ College Degree & 7,588 & $\begin{array}{l}-1.899 \\
(2.800)\end{array}$ & $\begin{array}{l}-0.285 \\
(1.324)\end{array}$ & $\begin{array}{l}-2.095 \\
(2.154)\end{array}$ & $\begin{array}{c}1.004 \\
(2.618)\end{array}$ & $\begin{array}{l}-0.247 \\
(0.939)\end{array}$ \\
\hline$<$ College Degree, all & 20,299 & $\begin{array}{l}3.732 * \\
(2.260)\end{array}$ & $\begin{array}{l}-0.369 \\
(1.154)\end{array}$ & $\begin{array}{c}1.432 \\
(2.390)\end{array}$ & $\begin{array}{c}0.016 \\
(1.263)\end{array}$ & $\begin{array}{c}0.821 \\
(0.679)\end{array}$ \\
\hline Black / Other Races & 4,874 & $\begin{array}{c}2.460 \\
(4.880)\end{array}$ & $\begin{array}{c}1.233 \\
(2.189)\end{array}$ & $\begin{array}{c}4.781 \\
(4.060)\end{array}$ & $\begin{array}{c}1.514 \\
(3.846)\end{array}$ & $\begin{array}{c}1.072 \\
(1.285)\end{array}$ \\
\hline White & 15,425 & $\begin{array}{c}4.219 \\
(2.664)\end{array}$ & $\begin{array}{l}-0.570 \\
(1.188)\end{array}$ & $\begin{array}{c}0.963 \\
(2.571)\end{array}$ & $\begin{array}{c}0.232 \\
(1.472)\end{array}$ & $\begin{array}{c}0.859 \\
(0.751)\end{array}$ \\
\hline Hispanic & 2,781 & $\begin{array}{c}2.220 \\
(7.969)\end{array}$ & $\begin{array}{c}1.140 \\
(2.930)\end{array}$ & $\begin{array}{c}5.501 \\
(5.693)\end{array}$ & $\begin{array}{l}-6.157 * \\
(3.242)\end{array}$ & $\begin{array}{c}0.907 \\
(1.024)\end{array}$ \\
\hline \multicolumn{7}{|c|}{ Panel 3: $<\$ 75,000$ in Financial Assets and $<$ College Degree } \\
\hline $\begin{array}{l}\geq \$ 75,000 \text { and } \\
\geq \text { College Degree }\end{array}$ & 5,292 & $\begin{array}{l}-3.655 \\
(3.886)\end{array}$ & $\begin{array}{l}-0.094 \\
(1.457)\end{array}$ & $\begin{array}{l}-3.557 \\
(2.821)\end{array}$ & $\begin{array}{c}1.811 \\
(3.061)\end{array}$ & $\begin{array}{l}-0.595 \\
(1.231)\end{array}$ \\
\hline $\begin{array}{l}<\$ 75,000 \text { and } \\
<\text { College Degree, all }\end{array}$ & 12,654 & $\begin{array}{c}0.947 \\
(3.064)\end{array}$ & $\begin{array}{l}-1.912 \\
(1.507)\end{array}$ & $\begin{array}{c}2.229 \\
(3.326)\end{array}$ & $\begin{array}{l}-1.222 \\
(2.040)\end{array}$ & $\begin{array}{c}0.868 \\
(0.919)\end{array}$ \\
\hline Black / Other Races & 4,100 & $\begin{array}{c}3.650 \\
(5.259)\end{array}$ & $\begin{array}{c}1.060 \\
(2.390)\end{array}$ & $\begin{array}{c}6.207 \\
(4.740)\end{array}$ & $\begin{array}{c}0.517 \\
(4.155)\end{array}$ & $\begin{array}{c}1.153 \\
(1.561)\end{array}$ \\
\hline White & 8,554 & $\begin{array}{c}0.359 \\
(3.733)\end{array}$ & $\begin{array}{l}-2.626 \\
(1.795)\end{array}$ & $\begin{array}{c}1.371 \\
(3.899)\end{array}$ & $\begin{array}{l}-1.221 \\
(2.213)\end{array}$ & $\begin{array}{c}1.038 \\
(1.107)\end{array}$ \\
\hline Hispanic & 2,342 & $\begin{array}{c}-2.116 \\
(10.376)\end{array}$ & $\begin{array}{c}0.419 \\
(2.833)\end{array}$ & $\begin{array}{c}6.694 \\
(7.063)\end{array}$ & $\begin{array}{l}-2.560 \\
(3.833)\end{array}$ & $\begin{array}{c}0.552 \\
(1.492)\end{array}$ \\
\hline
\end{tabular}

Standard errors are clustered by commuting zone. All regressions include individual and year fixed effects and are weighted to represent the target population. ${ }^{*} \mathrm{p}<0.10,{ }^{* *} \mathrm{p}<0.05,{ }^{* * *} \mathrm{p}<0.01$ 
Appendix Table C.1: Effect of the House Price Index on Senior Mental Health

\begin{tabular}{|c|c|c|c|c|c|}
\hline & $\begin{array}{c}(1) \\
\text { Depression }\end{array}$ & $\begin{array}{c}(2) \\
\text { Chronic } \\
\text { Pain }\end{array}$ & $\begin{array}{c}\text { (3) } \\
\text { Functional } \\
\text { Limitations }\end{array}$ & $\begin{array}{c}\text { (4) } \\
\text { Anxiety/ } \\
\text { Depression } \\
\text { Medications }\end{array}$ & $\begin{array}{c}\text { (5) } \\
\text { Sleep } \\
\text { Medications }\end{array}$ \\
\hline \multicolumn{6}{|l|}{ Panel 1: Full Sample } \\
\hline House Price Index & $\begin{array}{c}0.013 \\
(0.070)\end{array}$ & $\begin{array}{l}-0.022 \\
(0.037)\end{array}$ & $\begin{array}{l}-0.088 \\
(0.072)\end{array}$ & $\begin{array}{l}-0.021 \\
(0.066)\end{array}$ & $\begin{array}{l}-0.012 \\
(0.019)\end{array}$ \\
\hline Observations & 44881 & 47746 & 47912 & 6901 & 26610 \\
\hline Number of clusters & 426 & 434 & 434 & 274 & 396 \\
\hline \multicolumn{6}{|l|}{ Panel 2: Homeowners } \\
\hline House Price Index & $\begin{array}{c}0.014 \\
(0.080)\end{array}$ & $\begin{array}{l}-0.021 \\
(0.038)\end{array}$ & $\begin{array}{l}-0.084 \\
(0.069)\end{array}$ & $\begin{array}{c}0.005 \\
(0.076)\end{array}$ & $\begin{array}{l}-0.013 \\
(0.020)\end{array}$ \\
\hline Observations & 39650 & 42175 & 42318 & 5582 & 23788 \\
\hline Number of clusters & 402 & 408 & 408 & 254 & 369 \\
\hline \multicolumn{6}{|c|}{ Panel 3: Homeowners of one home } \\
\hline House Price Index & $\begin{array}{l}-0.020 \\
(0.090)\end{array}$ & $\begin{array}{l}-0.023 \\
(0.045)\end{array}$ & $\begin{array}{l}-0.131 \\
(0.081)\end{array}$ & $\begin{array}{l}-0.023 \\
(0.076)\end{array}$ & $\begin{array}{l}-0.004 \\
(0.027)\end{array}$ \\
\hline Observations & 33602 & 35828 & 35953 & 4936 & 19631 \\
\hline Number of clusters & 395 & 401 & 401 & 247 & 355 \\
\hline \multicolumn{6}{|l|}{ Panel 4: Not homeowner } \\
\hline House Price Index & $\begin{array}{c}0.006 \\
(0.218)\end{array}$ & $\begin{array}{l}-0.025 \\
(0.099)\end{array}$ & $\begin{array}{l}-0.078 \\
(0.178)\end{array}$ & $\begin{array}{c}-0.132 * \\
(0.079)\end{array}$ & $\begin{array}{l}-0.010 \\
(0.060)\end{array}$ \\
\hline Observations & 5231 & 5571 & 5594 & 1319 & 2822 \\
\hline Number of clusters & 196 & 200 & 200 & 136 & 177 \\
\hline
\end{tabular}

Standard errors are clustered by core-based statistical area. All regressions include individual and year fixed effects and are weighted to represent a nationally representative sample of 65- to 74-year-old adults. $* \mathrm{p}<0.10, * * \mathrm{p}<0.05, * * * \mathrm{p}<0.01$ 
Appendix Table C.2. Additional Effect of House Price Changes on Seniors by Race, Education, Financial Assets, and Tenure

\begin{tabular}{lccccc}
\hline & $(1)$ & $(2)$ & $(3)$ & $(4)$ & $(5)$ \\
& Depression & Chronic Pain & $\begin{array}{c}\text { Functional } \\
\text { Limitations }\end{array}$ & $\begin{array}{c}\text { Anxiety/ } \\
\text { Depression } \\
\text { Medications }\end{array}$ & $\begin{array}{c}\text { Sleep } \\
\text { Medications }\end{array}$ \\
\hline House Price Index & 0.007 & -0.021 & -0.119 & 0.010 & -0.004 \\
& $(0.076)$ & $(0.036)$ & $(0.081)$ & $(0.072)$ & $(0.020)$ \\
x $<\$$ 75,000 in financial assets & -0.025 & -0.013 & -0.103 & -0.013 & 0.034 \\
& $(0.066)$ & $(0.035)$ & $(0.074)$ & $(0.070)$ & $(0.024)$ \\
x Black and Other Races & -0.107 & -0.060 & 0.035 & 0.090 & 0.038 \\
& $(0.134)$ & $(0.069)$ & $(0.136)$ & $(0.093)$ & $(0.047)$ \\
x Hispanic & -0.020 & $-0.147 * *$ & -0.090 & 0.007 & 0.037 \\
& $(0.172)$ & $(0.067)$ & $(0.130)$ & $(0.110)$ & $(0.050)$ \\
x C College degree & 0.087 & -0.003 & 0.001 & -0.062 & -0.017 \\
x Recent homeowner & $(0.100)$ & $(0.044)$ & $(0.079)$ & $(0.158)$ & $(0.034)$ \\
x Not homeowner & 0.316 & -0.041 & 0.136 & -0.238 & 0.076 \\
x Recently sold & $(0.316)$ & $(0.165)$ & $(0.308)$ & $(0.217)$ & $(0.047)$ \\
Observations & 0.021 & -0.054 & $-0.264 * *$ & 0.070 & 0.040 \\
& $(0.151)$ & $(0.080)$ & $(0.123)$ & $(0.100)$ & $(0.041)$ \\
& 0.110 & 0.144 & -0.502 & 0.318 & -0.001 \\
& $(0.521)$ & $(0.162)$ & $(0.394)$ & $(0.237)$ & $(0.078)$ \\
& 40,154 & 42,701 & 42,856 & 6,074 & 24,195 \\
\hline
\end{tabular}

Standard errors are clustered by core-based statistical area. All regressions include individual and year fixed effects and are weighted to represent a nationally representative sample of 65- to 74-year-old adults. ${ }^{*} \mathrm{p}<0.10, * * \mathrm{p}<0.05,{ }^{* * *} \mathrm{p}<0.01$ 
Appendix Table C.3. Heterogeneous effects of the House Price Decline among Seniors

\begin{tabular}{|c|c|c|c|c|c|c|}
\hline & & (1) & (2) & (3) & (4) & $(5)$ \\
\hline & Observations & Depression & $\begin{array}{c}\text { Pain } \\
\text { Severity }\end{array}$ & $\begin{array}{l}\text { Functional } \\
\text { Limitations }\end{array}$ & $\begin{array}{c}\text { Anxiety / } \\
\text { Depression } \\
\text { Medication }\end{array}$ & $\begin{array}{c}\text { Sleep } \\
\text { Medication }\end{array}$ \\
\hline \multicolumn{7}{|c|}{ Panel 1: $<\$ 75,000$ in Financial Assets } \\
\hline$\geq \$ 75,000$ & 23,055 & $\begin{array}{c}0.059 \\
(0.107)\end{array}$ & $\begin{array}{c}0.029 \\
(0.047)\end{array}$ & $\begin{array}{c}-0.004 \\
(0.081)\end{array}$ & $\begin{array}{c}0.018 \\
(0.131)\end{array}$ & $\begin{array}{l}-0.036 \\
(0.025)\end{array}$ \\
\hline$<\$ 75,000$, all & 24,859 & $\begin{array}{l}-0.000 \\
(0.134)\end{array}$ & $\begin{array}{l}-0.095 \\
(0.068)\end{array}$ & $\begin{array}{l}-0.127 \\
(0.147)\end{array}$ & $\begin{array}{c}0.054 \\
(0.086)\end{array}$ & $\begin{array}{c}0.025 \\
(0.037)\end{array}$ \\
\hline Black / Other Races & 7,380 & $\begin{array}{c}0.235 \\
(0.252)\end{array}$ & $\begin{array}{l}-0.001 \\
(0.115)\end{array}$ & $\begin{array}{l}-0.042 \\
(0.283)\end{array}$ & $\begin{array}{c}0.170 \\
(0.151)\end{array}$ & $\begin{array}{c}0.132 \\
(0.101)\end{array}$ \\
\hline White & 17,479 & $\begin{array}{l}-0.068 \\
(0.177)\end{array}$ & $\begin{array}{l}-0.123 \\
(0.077)\end{array}$ & $\begin{array}{l}-0.161 \\
(0.191)\end{array}$ & $\begin{array}{c}0.046 \\
(0.094)\end{array}$ & $\begin{array}{c}0.003 \\
(0.037)\end{array}$ \\
\hline Hispanic & 3,598 & $\begin{array}{c}0.091 \\
(0.309)\end{array}$ & $\begin{array}{c}-0.270 * \\
(0.142)\end{array}$ & $\begin{array}{l}-0.129 \\
(0.283)\end{array}$ & $\begin{array}{c}0.150 \\
(0.180)\end{array}$ & $\begin{array}{c}0.086 \\
(0.086)\end{array}$ \\
\hline \multicolumn{7}{|l|}{ Panel 2: $<$ College Degree } \\
\hline$\geq$ College Degree & 9,564 & $\begin{array}{l}-0.091 \\
(0.150)\end{array}$ & $\begin{array}{c}0.067 \\
(0.056)\end{array}$ & $\begin{array}{l}-0.017 \\
(0.112)\end{array}$ & $\begin{array}{c}0.049 \\
(0.214)\end{array}$ & $\begin{array}{c}0.022 \\
(0.029)\end{array}$ \\
\hline$<$ College Degree, all & 38,350 & $\begin{array}{c}0.052 \\
(0.085)\end{array}$ & $\begin{array}{l}-0.045 \\
(0.048)\end{array}$ & $\begin{array}{l}-0.096 \\
(0.076)\end{array}$ & $\begin{array}{l}-0.018 \\
(0.072)\end{array}$ & $\begin{array}{l}-0.023 \\
(0.025)\end{array}$ \\
\hline Black / Other Races & 7,986 & $\begin{array}{c}0.214 \\
(0.231)\end{array}$ & $\begin{array}{l}-0.075 \\
(0.094)\end{array}$ & $\begin{array}{c}0.025 \\
(0.254)\end{array}$ & $\begin{array}{c}0.110 \\
(0.142)\end{array}$ & $\begin{array}{c}0.096 \\
(0.072)\end{array}$ \\
\hline White & 30,364 & $\begin{array}{c}0.023 \\
(0.096)\end{array}$ & $\begin{array}{l}-0.043 \\
(0.053)\end{array}$ & $\begin{array}{l}-0.118 \\
(0.091)\end{array}$ & $\begin{array}{l}-0.027 \\
(0.075)\end{array}$ & $\begin{array}{l}-0.038 \\
(0.024)\end{array}$ \\
\hline Hispanic & 4,084 & $\begin{array}{l}-0.005 \\
(0.236)\end{array}$ & $\begin{array}{c}-0.237 * * \\
(0.115)\end{array}$ & $\begin{array}{l}-0.091 \\
(0.239)\end{array}$ & $\begin{array}{c}0.058 \\
(0.163)\end{array}$ & $\begin{array}{c}0.045 \\
(0.068)\end{array}$ \\
\hline \multicolumn{7}{|c|}{ Panel 3: $<\$ 75,000$ in Financial Assets and $<$ College Degree } \\
\hline $\begin{array}{l}\geq \$ 75,000 \text { and } \\
\geq \text { College Degree }\end{array}$ & 7,361 & $\begin{array}{c}0.041 \\
(0.152)\end{array}$ & $\begin{array}{c}0.023 \\
(0.061)\end{array}$ & $\begin{array}{c}0.067 \\
(0.122)\end{array}$ & $\begin{array}{l}-0.001 \\
(0.299)\end{array}$ & $\begin{array}{c}0.011 \\
(0.030)\end{array}$ \\
\hline $\begin{array}{l}<\$ 75,000 \text { and } \\
<\text { College Degree, all }\end{array}$ & 22,656 & $\begin{array}{c}0.071 \\
(0.133)\end{array}$ & $\begin{array}{l}-0.125^{*} \\
(0.072)\end{array}$ & $\begin{array}{l}-0.118 \\
(0.144)\end{array}$ & $\begin{array}{c}0.045 \\
(0.088)\end{array}$ & $\begin{array}{c}0.014 \\
(0.037)\end{array}$ \\
\hline Black / Other Races & 6,806 & $\begin{array}{c}0.442 \\
(0.275)\end{array}$ & $\begin{array}{l}-0.053 \\
(0.114)\end{array}$ & $\begin{array}{l}-0.024 \\
(0.290)\end{array}$ & $\begin{array}{c}0.156 \\
(0.151)\end{array}$ & $\begin{array}{c}0.134 \\
(0.105)\end{array}$ \\
\hline White & 15,850 & $\begin{array}{l}-0.027 \\
(0.176)\end{array}$ & $\begin{array}{l}-0.147^{*} \\
(0.081)\end{array}$ & $\begin{array}{l}-0.152 \\
(0.185)\end{array}$ & $\begin{array}{c}0.037 \\
(0.097)\end{array}$ & $\begin{array}{l}-0.011 \\
(0.036)\end{array}$ \\
\hline Hispanic & 3,492 & $\begin{array}{c}0.114 \\
(0.310)\end{array}$ & $\begin{array}{c}-0.292 * * \\
(0.144)\end{array}$ & $\begin{array}{l}-0.144 \\
(0.289)\end{array}$ & $\begin{array}{c}0.134 \\
(0.185)\end{array}$ & $\begin{array}{c}0.085 \\
(0.085)\end{array}$ \\
\hline
\end{tabular}

Standard errors are clustered by core-based statistical area. All regressions include individual and year fixed effects and are weighted to represent a nationally representative sample of 65 - to 74 -year-old adults. ${ }^{*} \mathrm{p}<0.10,{ }^{* *} \mathrm{p}<0.05$, ${ }^{* * *}$ $\mathrm{p}<0.01$ 


\begin{tabular}{l} 
Variable \\
\hline Individual level \\
Housing value and debt \\
Fraction of housing \\
wealth lost \\
$\$ 1000$ dollars of \\
housing wealth \\
Debt
\end{tabular}

Income effects

Difficulty paying monthly bills

Foreclosure and arrears

Fell behind on mortgage Foreclosed upon Likelihood of falling behind on mortgage

Job loss

Self-rated probability of losing job

Stress and social isolation

Social isolation

Stress

\section{Family level}

Foreclosure and Arrears Family fell behind mortgage

Family member was foreclosed upon

Financial network Gave financial help to a child
Definition

Fraction of lost housing wealth lost is calculated relative to most recent observation prior to 2006 .

Self-reported home values in thousand dollar increments. Applies to the respondent's primary place of residence only.

Reported in nominal dollars and based on RAND's calculation of household debt, which is drawn from the combination of two questions:

1. do you [or your (husband/wife/partner)] have any debts that we haven't asked about, such as credit card balances, medical debts, life insurance policy loans, loans from relatives, and so forth?

2. About how much would that amount to?

How difficult is it for (you/your family) to meet monthly payments on (your/your family's) bills? Scale 0 (not at all difficult) to 5 (completely difficult)

Have you fallen more than 2 months behind on mortgage payments in the past 2 years? (yes/no)

Have you gone through a foreclosure in the past 2 years? (yes/no)

How likely is it that you will fall behind in your mortgage payments during the next 6 months -- is it very likely, somewhat likely, or not likely at all?

Scale 1 (not likely at all) to 3 (very likely); reverse coded in the HRS

How often do you feel isolated from others? Scale 1 (hardly ever) to 3 (often); reverse coded in the HRS

A binary variable that is 1 if reports any of the following manifestations of stress:

- In the last two years, have you had back pain or problems?

- In the last two years, have you had any persistence headaches?

- In the last two years, have you had any severe fatigue or exhaustion?

Not counting you [or your husband/wife/partner/ ], has anyone in your immediate family fallen more than 2 months behind on mortgage payments in the past 2 years? (yes/no)

Has anyone in your immediate family gone through a foreclosure in the past 2 years? (yes/no)

Including help with education but not shared housing or shared food [or any deed to a house], [[since [ [Previous wave interview month of family $\mathrm{R}] /$ Refusal/Don't know], in the last two years did you [or your 
Gave financial help to a relative

Received financial help from family

Received financial help from a child

\section{Neighborhood level}

Many vacant or deserted houses or storefronts Feel safe after dark

I feel like I belong in my neighborhood I can get help from my neighbors

Trust in neighbors

Graffiti in neighborhood

Friendly neighbors

Clean neighborhood husband/wife/partner/ ] [ late/ husband/ wife/ partner] give financial help totaling $\$ 500$ or more to [ [her /his /your ] child /any of [her /his /your ] children ] (or grandchild(ren))?

[The next questions are about help you [or your husband/wife/partner/ ] gave or received [[since [Previous Wave Month], [PREV WAVE IW YEAR OF FAMILY R] Did you [or your husband/wife/partner/ ] [ or your] [ late/ husband/ wife/ partner] give financial help totaling $\$ 500$ or more in the last two years]] to friends or relatives [other than children, grandchildren, greatgrandchildren, or parents?/other than children, grandchildren, or parents?/other than children or parents?] Do not count shared housing or shared food.

Not counting any shared housing or shared food, did you [or your] [ late/husband/wife/partner] receive from your [family member (and/or her husband)/father (and/or his wife)] any financial help amounting to $\$ 500$ or more in the last two years]? Do not include inheritance.

In the last two years did you [or your husband/wife/partner/ ] [ or your] [ late/ husband/ wife/ partner] receive financial help totaling $\$ 500$ or more from [ [her /his /your ] child /any of [her /his /your ] children ] (or grandchild(ren))?

There are many vacant or deserted houses or storefronts (w/in 20 min walk / 1 mile of my home) Scale: 0 (strongly disagree) to 7 (strongly agree).

People would be afraid to walk alone in this area after dark (w/in $20 \mathrm{~min}$ walk / 1 mile of my home). Scale: 0 (strongly disagree) to 7 (strongly agree). I feel I belong in my area (w/in 20 min walk / 1 mile of my home). Scale: 0 (strongly disagree) to 7 (strongly agree).

There are lots of people in area who would help if I were in trouble (w/in 20 min walk / 1 mile of my home). Scale: 0 (strongly disagree) to 7 (strongly agree).

Most people in area can be trusted (w/in 20 min walk / 1 mile of my home). Scale: 0 (strongly disagree) to 7 (strongly agree).

Vandalism/graffiti is a big problem in my area (w/in 20 min walk / 1 mile of my home). Scale: 0 (strongly disagree) to 7 (strongly agree).

Most people in this area are friendly (w/in 20 min walk / 1 mile of my home). Scale: 0 (strongly disagree) to 7 (strongly agree).

This area is kept very clean (w/in 20 min walk / 1 mile of my home). Scale: 0 (strongly disagree) to 7 (strongly agree).

Financial help refers to giving money, helping pay bills, or covering specific types of costs such as those for medical care OR insurance, schooling, down payment for a home, rent, etc. The financial help can be considered support, a gift or a loan.) 
Appendix Table D.2. Potential Mechanisms (page 1 of 3)

\begin{tabular}{|c|c|c|c|c|c|c|c|c|c|}
\hline & $\begin{array}{l}\text { Fraction of } \\
\text { housing } \\
\text { wealth lost }\end{array}$ & $\begin{array}{c}\$ 1000 \\
\text { dollars of } \\
\text { Housing } \\
\text { wealth }\end{array}$ & Debt & $\begin{array}{l}\text { Trouble } \\
\text { Monthly } \\
\text { Bills }\end{array}$ & $\begin{array}{l}\text { Fell behind } \\
\text { mortgage }\end{array}$ & $\begin{array}{l}\text { Foreclosed } \\
\text { upon }\end{array}$ & $\begin{array}{c}\text { Likelihood } \\
\text { of falling } \\
\text { behind on } \\
\text { mortgage }\end{array}$ & $\begin{array}{c}\text { Self-rated } \\
\text { probability } \\
\text { of losing } \\
\text { job }\end{array}$ & $\begin{array}{c}\text { Feel } \\
\text { isolated }\end{array}$ \\
\hline \multicolumn{10}{|c|}{ Homeowners with $>75 \mathrm{~K}$ in financial assets } \\
\hline House Price Index & $\begin{array}{c}-0.701 * * * \\
(0.067)\end{array}$ & $\begin{array}{c}207.333 * * * \\
(38.610)\end{array}$ & $\begin{array}{c}825.901 \\
(3074.126)\end{array}$ & $\begin{array}{l}-0.180 \\
(0.227)\end{array}$ & $\begin{array}{l}-0.122 \\
(0.087)\end{array}$ & $\begin{array}{l}-0.041 \\
(0.048)\end{array}$ & $\begin{array}{l}-0.011 \\
(0.161)\end{array}$ & $\begin{array}{l}-1.793 \\
(3.760)\end{array}$ & $\begin{array}{l}-0.015 \\
(0.193)\end{array}$ \\
\hline Observations & 12080 & 12726 & 12726 & 2634 & 1394 & 1394 & 1160 & 5772 & 2631 \\
\hline Number of clusters & 273 & 284 & 284 & 174 & 114 & 114 & 103 & 234 & 173 \\
\hline \multicolumn{10}{|c|}{ Homeowners with $<75 \mathrm{~K}$ in financial assets } \\
\hline House Price Index & $\begin{array}{c}-0.678 * * * \\
(0.073)\end{array}$ & $\begin{array}{c}103.853 * * * \\
(17.298)\end{array}$ & $\begin{array}{l}-3988.856 \\
(2434.987)\end{array}$ & $\begin{array}{l}-0.347 \\
(0.347)\end{array}$ & $\begin{array}{l}-0.124 \\
(0.141)\end{array}$ & $\begin{array}{l}-0.019 \\
(0.065)\end{array}$ & $\begin{array}{l}-0.053 \\
(0.366)\end{array}$ & $\begin{array}{l}-4.959 \\
(4.302)\end{array}$ & $\begin{array}{c}0.146 \\
(0.226)\end{array}$ \\
\hline Observations & 10766 & 13606 & 13606 & 2688 & 1576 & 1575 & 1136 & 7019 & 2686 \\
\hline Number of clusters & 255 & 275 & 275 & 165 & 133 & 133 & 120 & 234 & 166 \\
\hline \multicolumn{10}{|c|}{ Black/Other homeowners with $<75 \mathrm{~K}$ in financial assets } \\
\hline House Price Index & $\begin{array}{c}-0.598 * * * \\
(0.152)\end{array}$ & $\begin{array}{c}90.865^{* * *} \\
(19.245)\end{array}$ & $\begin{array}{l}-2705.980 \\
(7112.626)\end{array}$ & $\begin{array}{l}-0.198 \\
(0.496)\end{array}$ & $\begin{array}{c}0.236 \\
(0.262)\end{array}$ & $\begin{array}{c}0.050 \\
(0.176)\end{array}$ & $\begin{array}{c}1.082 \\
(1.666)\end{array}$ & $\begin{array}{l}-9.632 \\
(6.149)\end{array}$ & $\begin{array}{c}0.023 \\
(0.434)\end{array}$ \\
\hline Observations & 2809 & 4167 & 4167 & 812 & 421 & 421 & 275 & 1983 & 810 \\
\hline Number of clusters & 122 & 139 & 139 & 89 & 71 & 71 & 55 & 110 & 89 \\
\hline \multicolumn{10}{|c|}{ White homeowners with $<75 \mathrm{~K}$ in financial asset } \\
\hline House Price Index & $\begin{array}{c}-0.708 * * * \\
(0.084)\end{array}$ & $\begin{array}{c}108.965^{* * *} \\
(19.386)\end{array}$ & $\begin{array}{l}-4544.640 * \\
(2463.509)\end{array}$ & $\begin{array}{l}-0.383 \\
(0.428)\end{array}$ & $\begin{array}{l}-0.194 \\
(0.130)\end{array}$ & $\begin{array}{l}-0.057 \\
(0.059)\end{array}$ & $\begin{array}{l}-0.185 \\
(0.344)\end{array}$ & $\begin{array}{l}-3.273 \\
(5.429)\end{array}$ & $\begin{array}{c}0.163 \\
(0.272)\end{array}$ \\
\hline Observations & 7957 & 9439 & 9439 & 1876 & 1155 & 1154 & 861 & 5036 & 1876 \\
\hline Number of clusters & 234 & 248 & 248 & 158 & 125 & 125 & 115 & 218 & 159 \\
\hline \multicolumn{10}{|c|}{ Homeowners with $<75 \mathrm{~K}$ in financial assets and $<$ a college degree } \\
\hline House Price Index & $\begin{array}{c}-0.699 * * * \\
(0.078)\end{array}$ & $\begin{array}{c}95.493 * * * \\
(16.057)\end{array}$ & $\begin{array}{l}-3880.241 \\
(2580.166)\end{array}$ & $\begin{array}{l}-0.362 \\
(0.385)\end{array}$ & $\begin{array}{l}-0.137 \\
(0.153)\end{array}$ & $\begin{array}{c}0.000 \\
(0.084)\end{array}$ & $\begin{array}{c}0.119 \\
(0.395)\end{array}$ & $\begin{array}{l}-3.826 \\
(4.824)\end{array}$ & $\begin{array}{c}0.060 \\
(0.224)\end{array}$ \\
\hline Observations & 8931 & 11420 & 11420 & 2228 & 1223 & 1222 & 851 & 5699 & 2225 \\
\hline Number of clusters & 235 & 254 & 254 & $\begin{array}{r}157 \\
26\end{array}$ & 123 & 123 & 112 & 213 & 158 \\
\hline
\end{tabular}


Black/Other homeowners with $<75 \mathrm{~K}$ in financial assets and $<$ a college degree

\begin{tabular}{lccccccccc} 
House Price Index & $-0.548^{* *}$ & $74.921^{* * *}$ & -4177.001 & -0.171 & 0.147 & 0.054 & 1.186 & -7.378 & 0.157 \\
& $(0.228)$ & $(19.952)$ & $(10276.894)$ & $(0.610)$ & $(0.496)$ & $(0.241)$ & $(2.661)$ & $(8.638)$ & $(0.502)$ \\
Observations & 2016 & 3245 & 3245 & 643 & 307 & 307 & 183 & 1495 & 644 \\
Number of clusters & 110 & 126 & 126 & 81 & 63 & 63 & 49 & 104 & 81 \\
hite homeowners with & $<75 \mathrm{~K}$ in financial assets and $<$ a college degree & & & & & \\
\multicolumn{2}{l}{} \\
House Price Index & $-0.612^{* * *}$ & $73.248^{* * *}$ & -5674.723 & -0.550 & -0.156 & -0.036 & -0.144 & -1.642 & -0.040 \\
& $(0.107)$ & $(12.948)$ & $(3779.867)$ & $(0.541)$ & $(0.245)$ & $(0.085)$ & $(0.614)$ & $(6.950)$ & $(0.423)$ \\
Observations & 4758 & 5941 & 5941 & 1237 & 743 & 742 & 521 & 3017 & 1237 \\
Number of clusters & 192 & 209 & 209 & 138 & 113 & 113 & 105 & 187 & 138 \\
\hline
\end{tabular}

Standard errors are clustered by core-based statistical area. All regressions include individual and year fixed effects and are weighted to represent a nationally representative sample of 51- to 61 -year-old adults. $* \mathrm{p}<0.10, * * \mathrm{p}<0.05, * * * \mathrm{p}<0.01$. Detailed definitions for all mechanisms in this table can be found in Appendix Table C.1. 
Appendix D.2. Potential Mechanisms continued (page 2 of 3)

\begin{tabular}{|c|c|c|c|c|c|c|c|c|}
\hline & Stress & $\begin{array}{c}\text { Family fell } \\
\text { behind } \\
\text { mortgage }\end{array}$ & $\begin{array}{l}\text { Family } \\
\text { member } \\
\text { was } \\
\text { foreclosed } \\
\text { upon }\end{array}$ & $\begin{array}{l}\text { Gave } \\
\text { financial } \\
\text { help to a } \\
\text { child }\end{array}$ & $\begin{array}{l}\text { Gave } \\
\text { financial } \\
\text { help to a } \\
\text { relative }\end{array}$ & $\begin{array}{l}\text { Received } \\
\text { financial } \\
\text { help from } \\
\text { family }\end{array}$ & $\begin{array}{l}\text { Received } \\
\text { financial } \\
\text { help from } \\
\text { a child }\end{array}$ & $\begin{array}{c}\text { Many } \\
\text { vacant or } \\
\text { deserted } \\
\text { houses or } \\
\text { storefronts }\end{array}$ \\
\hline \multicolumn{9}{|c|}{ Homeowners with $>75 \mathrm{~K}$ in financial assets } \\
\hline House Price Index & $\begin{array}{l}-0.014 \\
(0.038)\end{array}$ & $\begin{array}{l}-0.042 \\
(0.096)\end{array}$ & $\begin{array}{l}-0.438 \\
(3.350)\end{array}$ & $\begin{array}{c}0.032 \\
(0.051)\end{array}$ & $\begin{array}{c}0.022 \\
(0.036)\end{array}$ & $\begin{array}{c}0.013 \\
(0.021)\end{array}$ & $\begin{array}{l}-0.015 \\
(0.010)\end{array}$ & $\begin{array}{l}-0.291 \\
(0.873)\end{array}$ \\
\hline Observations & 12593 & 2978 & 224 & 11669 & 12568 & 11731 & 11712 & 2634 \\
\hline Number of clusters & 283 & 161 & 69 & 278 & 281 & 278 & 277 & 173 \\
\hline \multicolumn{9}{|c|}{ Homeowners with $<75 \mathrm{~K}$ in financial assets } \\
\hline House Price Index & $\begin{array}{l}-0.002 \\
(0.039)\end{array}$ & $\begin{array}{l}-0.193 \\
(0.140)\end{array}$ & $\begin{array}{c}0.089 \\
(2.851)\end{array}$ & $\begin{array}{l}-0.018 \\
(0.064)\end{array}$ & $\begin{array}{l}-0.007 \\
(0.029)\end{array}$ & $\begin{array}{c}0.024 \\
(0.040)\end{array}$ & $\begin{array}{c}0.026 \\
(0.032)\end{array}$ & $\begin{array}{c}0.094 \\
(1.060)\end{array}$ \\
\hline Observations & 13388 & 3414 & 399 & 12565 & 13384 & 12674 & 12594 & 2667 \\
\hline Number of clusters & 273 & 157 & 85 & 267 & 274 & 268 & 267 & 166 \\
\hline \multicolumn{9}{|c|}{ Black/Other homeowners with $<75 \mathrm{~K}$ in financial assets } \\
\hline House Price Index & $\begin{array}{l}-0.007 \\
(0.058)\end{array}$ & $\begin{array}{l}-0.273 \\
(0.322)\end{array}$ & $\begin{array}{l}-2.998 \\
(6.484)\end{array}$ & $\begin{array}{l}-0.061 \\
(0.104)\end{array}$ & $\begin{array}{l}-0.047 \\
(0.050)\end{array}$ & $\begin{array}{l}0.096^{*} \\
(0.055)\end{array}$ & $\begin{array}{l}0.093 * \\
(0.050)\end{array}$ & $\begin{array}{c}1.615 \\
(1.415)\end{array}$ \\
\hline Observations & 4082 & 1113 & 148 & 3864 & 4074 & 3884 & 3872 & 808 \\
\hline Number of clusters & 137 & 90 & 50 & 134 & 138 & 135 & 134 & 89 \\
\hline \multicolumn{9}{|c|}{ White homeowners with $<75 \mathrm{~K}$ in financial asset } \\
\hline House Price Index & $\begin{array}{l}-0.005 \\
(0.056)\end{array}$ & $\begin{array}{c}-0.183 \\
(0.130)\end{array}$ & $\begin{array}{c}0.398 \\
(3.281)\end{array}$ & $\begin{array}{c}0.000 \\
(0.078)\end{array}$ & $\begin{array}{c}0.004 \\
(0.036)\end{array}$ & $\begin{array}{c}0.003 \\
(0.048)\end{array}$ & $\begin{array}{c}0.002 \\
(0.035)\end{array}$ & $\begin{array}{l}-0.316 \\
(1.328)\end{array}$ \\
\hline Observations & 9306 & 2301 & 251 & 8701 & 9310 & 8790 & 8722 & 1859 \\
\hline Number of clusters & 248 & 145 & 72 & 242 & 247 & 243 & 242 & 159 \\
\hline \multicolumn{9}{|c|}{ Homeowners with $<75 \mathrm{~K}$ in financial assets and $<$ a college degree } \\
\hline House Price Index & $\begin{array}{l}-0.007 \\
(0.045)\end{array}$ & $\begin{array}{l}-0.200 \\
(0.177)\end{array}$ & $\begin{array}{l}-0.051 \\
(2.733)\end{array}$ & $\begin{array}{l}-0.034 \\
(0.069)\end{array}$ & $\begin{array}{l}-0.011 \\
(0.031)\end{array}$ & $\begin{array}{c}0.031 \\
(0.042)\end{array}$ & $\begin{array}{c}0.037 \\
(0.035)\end{array}$ & $\begin{array}{c}0.298 \\
(1.066)\end{array}$ \\
\hline Observations & 11227 & 2798 & 345 & 10663 & 11241 & 10726 & 10682 & 2204 \\
\hline Number of clusters & 252 & 145 & 82 & 247 & 253 & 247 & 247 & 158 \\
\hline
\end{tabular}


Black/Other homeowners with $<75 \mathrm{~K}$ in financial assets and $<$ a college degree

\begin{tabular}{|c|c|c|c|c|c|c|c|c|}
\hline House Price Index & $\begin{array}{c}0.001 \\
(0.068)\end{array}$ & $\begin{array}{l}-0.504 \\
(0.357)\end{array}$ & $\begin{array}{l}-2.133 \\
(6.577)\end{array}$ & $\begin{array}{l}-0.114 \\
(0.148)\end{array}$ & $\begin{array}{l}-0.021 \\
(0.059)\end{array}$ & $\begin{array}{l}0.128^{*} \\
(0.076)\end{array}$ & $\begin{array}{c}0.124 * * \\
(0.062)\end{array}$ & $\begin{array}{c}1.928 \\
(1.939)\end{array}$ \\
\hline Observations & 3174 & 904 & 127 & 3008 & 3174 & 3022 & 3012 & 638 \\
\hline Number of clusters & 125 & 83 & 45 & 120 & 125 & 121 & 120 & 81 \\
\hline \multicolumn{9}{|c|}{ Jhite homeowners with $<75 \mathrm{~K}$ in financial assets and $<$ a college degree } \\
\hline House Price Index & $\begin{array}{l}-0.046 \\
(0.075)\end{array}$ & $\begin{array}{l}-0.261 \\
(0.174)\end{array}$ & $\begin{array}{l}-2.243 \\
(3.178)\end{array}$ & $\begin{array}{c}0.022 \\
(0.087)\end{array}$ & $\begin{array}{c}0.021 \\
(0.044)\end{array}$ & $\begin{array}{c}0.001 \\
(0.072)\end{array}$ & $\begin{array}{l}-0.009 \\
(0.055)\end{array}$ & $\begin{array}{c}0.140 \\
(1.803)\end{array}$ \\
\hline Observations & 5851 & 1582 & 175 & 5485 & 5856 & 5542 & 5494 & 1222 \\
\hline Number of clusters & 208 & 128 & 63 & 204 & 208 & 205 & 204 & 138 \\
\hline
\end{tabular}

Standard errors are clustered by core-based statistical area. All regressions include individual and year fixed effects and are weighted to represent a nationally representative sample of 51- to 61-year-old adults. ${ }^{*} \mathrm{p}<0.10, * * \mathrm{p}<0.05,{ }^{* *} \mathrm{p}<0.01$. Detailed definitions for all mechanisms in this table can be found in Appendix Table C.1. 
Appendix Table D.2. Potential Mechanisms continued (page 3 of 3)

\begin{tabular}{|c|c|c|c|c|c|c|c|c|}
\hline & $\begin{array}{l}\text { Feel safe } \\
\text { after dark }\end{array}$ & $\begin{array}{l}\text { I feel like I } \\
\text { belong in my } \\
\text { neighborhood }\end{array}$ & $\begin{array}{l}\text { I can get } \\
\text { help from } \\
\text { my } \\
\text { neighbors }\end{array}$ & $\begin{array}{c}\text { Trust in } \\
\text { neighbors }\end{array}$ & $\begin{array}{c}\text { Graffiti in } \\
\text { neighborhood }\end{array}$ & $\begin{array}{l}\text { Friendly } \\
\text { neighbors }\end{array}$ & $\begin{array}{c}\text { Clean } \\
\text { neighborhood }\end{array}$ & $\begin{array}{l}\text { I feel like I } \\
\text { belong in my } \\
\text { neighborhood }\end{array}$ \\
\hline \multicolumn{9}{|c|}{ Homeowners with $>75 \mathrm{~K}$ in financial assets } \\
\hline House Price Index & $\begin{array}{l}-0.850 \\
(0.534)\end{array}$ & $\begin{array}{c}-0.138 \\
(0.487)\end{array}$ & $\begin{array}{c}0.119 \\
(0.425)\end{array}$ & $\begin{array}{l}-0.006 \\
(0.455)\end{array}$ & $\begin{array}{l}-0.909 \\
(0.558)\end{array}$ & $\begin{array}{c}0.060 \\
(0.410)\end{array}$ & $\begin{array}{l}-0.291 \\
(0.455)\end{array}$ & $\begin{array}{l}-0.138 \\
(0.487)\end{array}$ \\
\hline Observations & 2631 & 2631 & 2636 & 2634 & 2636 & 2634 & 2635 & 2631 \\
\hline Number of clusters & 173 & 173 & 173 & 172 & 173 & 173 & 173 & 173 \\
\hline \multicolumn{9}{|c|}{ Homeowners with $<75 \mathrm{~K}$ in financial assets } \\
\hline House Price Index & $\begin{array}{l}-0.064 \\
(1.294)\end{array}$ & $\begin{array}{c}0.252 \\
(0.637)\end{array}$ & $\begin{array}{c}0.066 \\
(0.502)\end{array}$ & $\begin{array}{c}0.627 \\
(0.633)\end{array}$ & $\begin{array}{l}-0.661 \\
(1.229)\end{array}$ & $\begin{array}{c}0.085 \\
(0.502)\end{array}$ & $\begin{array}{c}0.117 \\
(0.482)\end{array}$ & $\begin{array}{c}0.252 \\
(0.637)\end{array}$ \\
\hline Observations & 2669 & 2680 & 2680 & 2661 & 2669 & 2675 & 2676 & 2680 \\
\hline Number of clusters & 166 & 166 & 166 & 166 & 166 & 166 & 166 & 166 \\
\hline \multicolumn{9}{|c|}{ Black/Other homeowners with $<75 \mathrm{~K}$ in financial assets } \\
\hline House Price Index & $\begin{array}{l}-0.186 \\
(1.984)\end{array}$ & $\begin{array}{l}-0.651 \\
(1.179)\end{array}$ & $\begin{array}{c}0.481 \\
(1.296)\end{array}$ & $\begin{array}{c}0.067 \\
(1.277)\end{array}$ & $\begin{array}{l}-0.601 \\
(2.178)\end{array}$ & $\begin{array}{l}-0.630 \\
(1.139)\end{array}$ & $\begin{array}{l}-0.818 \\
(1.118)\end{array}$ & $\begin{array}{l}-0.651 \\
(1.179)\end{array}$ \\
\hline Observations & 806 & 809 & 810 & 800 & 803 & 810 & 810 & 809 \\
\hline Number of clusters & 89 & 89 & 89 & 88 & 89 & 89 & 89 & 89 \\
\hline \multicolumn{9}{|c|}{ White homeowners with $<75 \mathrm{~K}$ in financial asset } \\
\hline House Price Index & $\begin{array}{c}0.114 \\
(1.626)\end{array}$ & $\begin{array}{c}0.508 \\
(0.686)\end{array}$ & $\begin{array}{l}-0.030 \\
(0.641)\end{array}$ & $\begin{array}{c}0.746 \\
(0.695)\end{array}$ & $\begin{array}{l}-0.566 \\
(1.409)\end{array}$ & $\begin{array}{c}0.219 \\
(0.575)\end{array}$ & $\begin{array}{c}0.294 \\
(0.624)\end{array}$ & $\begin{array}{c}0.508 \\
(0.686)\end{array}$ \\
\hline Observations & 1863 & 1871 & 1870 & 1861 & 1866 & 1865 & 1866 & 1871 \\
\hline Number of clusters & 159 & 159 & 159 & 159 & 159 & 159 & 159 & 159 \\
\hline \multicolumn{9}{|c|}{ Homeowners with $<75 \mathrm{~K}$ in financial assets and $<$ a college degree } \\
\hline House Price Index & $\begin{array}{c}0.097 \\
(1.583)\end{array}$ & $\begin{array}{c}0.079 \\
(0.660)\end{array}$ & $\begin{array}{c}0.031 \\
(0.601)\end{array}$ & $\begin{array}{c}0.529 \\
(0.652)\end{array}$ & $\begin{array}{l}-0.851 \\
(1.530)\end{array}$ & $\begin{array}{l}-0.026 \\
(0.633)\end{array}$ & $\begin{array}{c}0.142 \\
(0.568)\end{array}$ & $\begin{array}{c}0.079 \\
(0.660)\end{array}$ \\
\hline Observations & 2206 & 2218 & 2217 & 2199 & 2207 & 2212 & 2213 & 2218 \\
\hline Number of clusters & 158 & 158 & 158 & 157 & 158 & 158 & 158 & 158 \\
\hline
\end{tabular}


Black/Other homeowners with $<75 \mathrm{~K}$ in financial assets and $<$ a college degree

\begin{tabular}{lccccccccc} 
House Price Index & 0.787 & -1.113 & 0.671 & 0.189 & 0.040 & -0.628 & -1.145 & -1.113 \\
& $(1.936)$ & $(1.764)$ & $(1.742)$ & $(1.529)$ & $(2.230)$ & $(1.416)$ & $(1.401)$ & $(1.764)$ \\
Observations & 638 & 640 & 641 & 631 & 635 & 641 & 640 & 640 \\
Number of clusters & 81 & 81 & 81 & 80 & 81 & 81 & 81 & 81 \\
White homeowners with & $<75 \mathrm{~K}$ in financial assets and $<$ a college degree & & & & & \\
\multicolumn{2}{l}{} & 0.366 & 0.343 & 0.269 & 1.324 & -0.317 & 0.677 & 0.882 & 0.343 \\
House Price Index & $(2.103)$ & $(0.955)$ & $(1.130)$ & $(1.074)$ & $(1.805)$ & $(0.798)$ & $(0.911)$ & $(0.955)$ \\
Observations & 1227 & 1231 & 1232 & 1224 & 1227 & 1227 & 1229 & 1231 \\
Number of clusters & 138 & 138 & 138 & 138 & 138 & 138 & 138 & 138 \\
\hline
\end{tabular}

Standard errors are clustered by core-based statistical area. All regressions include individual and year fixed effects and are weighted to represent a nationally representative sample of 51 - to 61 -year-old adults. ${ }^{*} \mathrm{p}<0.10, * * \mathrm{p}<0.05,{ }^{* * *} \mathrm{p}<0.01$. Detailed definitions for all mechanisms in this table can be found in Appendix Table C.1. 
Appendix Table D.3 Change in Main Effect of the House Price Index with the Addition of Potential Mechanisms for Select Subpopulations

\begin{tabular}{|c|c|c|c|c|c|c|c|}
\hline \multirow[b]{3}{*}{ Dependent variable } & \multirow{3}{*}{$\begin{array}{c}\mathrm{HPI}^{\dagger} \text { only } \\
\text { main } \\
\text { effect (se) }\end{array}$} & \multicolumn{6}{|c|}{ With select additional mechanisms: } \\
\hline & & \multicolumn{2}{|c|}{$\begin{array}{c}\text { Fraction of housing } \\
\text { wealth lost }\end{array}$} & \multicolumn{2}{|c|}{ Housing wealth } & \multicolumn{2}{|c|}{$\begin{array}{c}\text { Vacant neighborhood } \\
\text { properties }\end{array}$} \\
\hline & & $\begin{array}{l}\text { HPI } \\
(\mathrm{se})\end{array}$ & $\begin{array}{l}\% \text { change } \\
\text { in HPI }\end{array}$ & $\begin{array}{l}\text { HPI } \\
(\mathrm{se})\end{array}$ & $\begin{array}{l}\% \text { change } \\
\text { in HPI }\end{array}$ & $\begin{array}{l}\text { HPI } \\
(\mathrm{se})\end{array}$ & $\begin{array}{l}\% \text { change } \\
\text { in HPI }\end{array}$ \\
\hline \multicolumn{8}{|c|}{ Panel 1: Black / Other, $<\$ 75,000$ in financial assets } \\
\hline Depression & $\begin{array}{c}-0.731 * * \\
(0.283)\end{array}$ & $\begin{array}{c}-0.783 * * \\
(0.321)\end{array}$ & $6.6 \%$ & $\begin{array}{c}-0.741 * * \\
(0.284)\end{array}$ & $1.4 \%$ & $\begin{array}{l}-0.998 \\
(1.219)\end{array}$ & $36.5 \%$ \\
\hline Chronic Pain & $\begin{array}{l}-0.137 \\
(0.134)\end{array}$ & $\begin{array}{c}0.001 \\
(0.149)\end{array}$ & $-100.7 \%$ & $\begin{array}{l}-0.133 \\
(0.134)\end{array}$ & $-2.9 \%$ & $\begin{array}{c}0.058 \\
(0.643)\end{array}$ & $-142.3 \%$ \\
\hline $\begin{array}{l}\text { Functional } \\
\text { Limitations }\end{array}$ & $\begin{array}{c}-0.508^{* *} \\
(0.212)\end{array}$ & $\begin{array}{l}-0.316 \\
(0.267)\end{array}$ & $-37.8 \%$ & $\begin{array}{c}-0.489 * * \\
(0.219)\end{array}$ & $-3.7 \%$ & $\begin{array}{l}-0.398 \\
(0.896)\end{array}$ & $-21.7 \%$ \\
\hline $\begin{array}{l}\text { Anxiety/ } \\
\text { Depression } \\
\text { Medication(s) }\end{array}$ & $\begin{array}{l}-0.151 \\
(0.216)\end{array}$ & $\begin{array}{l}-0.166 \\
(0.277)\end{array}$ & $9.9 \%$ & $\begin{array}{l}-0.119 \\
(0.216)\end{array}$ & $-21.2 \%$ & $\begin{array}{l}-0.173 \\
(1.164)\end{array}$ & $14.6 \%$ \\
\hline $\begin{array}{l}\text { Sleep } \\
\text { Medication(s) }\end{array}$ & $\begin{array}{l}-0.122 \\
(0.077)\end{array}$ & $\begin{array}{l}-0.116^{*} \\
(0.066)\end{array}$ & $-4.9 \%$ & $\begin{array}{l}-0.121 \\
(0.076)\end{array}$ & $-0.8 \%$ & $\begin{array}{l}-0.065 \\
(0.158)\end{array}$ & $-46.7 \%$ \\
\hline \multicolumn{8}{|c|}{ Panel 2: white, $<\$ 75,000$ in financial assets, and $<$ College Degree } \\
\hline Depression & $\begin{array}{c}0.233 \\
(0.273)\end{array}$ & $\begin{array}{c}0.165 \\
(0.255)\end{array}$ & $-29 \%$ & $\begin{array}{c}0.167 \\
(0.281)\end{array}$ & $-28 \%$ & & \\
\hline Chronic Pain & $\begin{array}{c}0.060 \\
(0.088)\end{array}$ & $\begin{array}{c}0.129 \\
(0.099)\end{array}$ & $115 \%$ & $\begin{array}{c}0.070 \\
(0.093)\end{array}$ & $17 \%$ & & \\
\hline $\begin{array}{l}\text { Functional } \\
\text { Limitations }\end{array}$ & $\begin{array}{l}-0.004 \\
(0.197)\end{array}$ & $\begin{array}{c}0.074 \\
(0.240)\end{array}$ & $-1950 \%$ & $\begin{array}{c}0.019 \\
(0.208)\end{array}$ & $-575 \%$ & & \\
\hline $\begin{array}{l}\text { Anxiety/ } \\
\text { Depression } \\
\text { Medication(s) }\end{array}$ & $\begin{array}{l}-0.193^{*} \\
(0.104)\end{array}$ & $\begin{array}{l}-0.121 \\
(0.162)\end{array}$ & $-37 \%$ & $\begin{array}{l}-0.203^{*} \\
(0.111)\end{array}$ & $5 \%$ & & \\
\hline $\begin{array}{l}\text { Sleep } \\
\text { Medication(s) }\end{array}$ & $\begin{array}{c}-0.150 * * \\
(0.070)\end{array}$ & $\begin{array}{l}-0.153^{*} \\
(0.078)\end{array}$ & $2 \%$ & $\begin{array}{c}-0.156^{* *} \\
(0.075)\end{array}$ & $4 \%$ & & \\
\hline
\end{tabular}

Estimates correspond to the main effect of the house price index in equation (1) run on each subgroup. Standard errors are clustered by core-based statistical area. All regressions include individual and year fixed effects and are weighted to represent a nationally representative sample of 51 - to 61 -year-old adults. ${ }^{\dagger}$ House price index. ${ }^{*}$ The fraction of lost housing wealth and housing wealth are based on the respondent's place of primary residence only. Definitions for all mechanisms in this table can be found in Appendix Table C.1. 